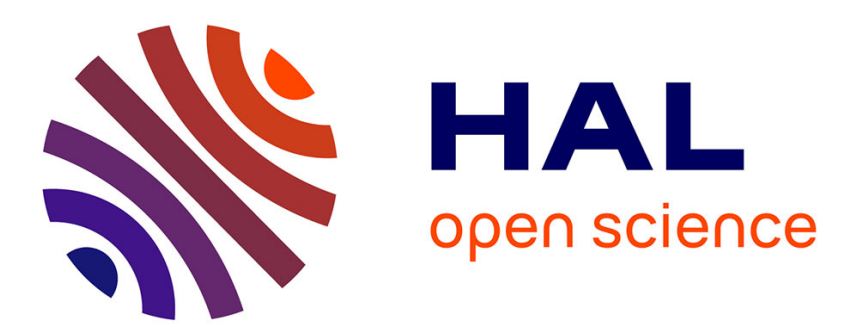

\title{
Storage and eruption of near-liquidus rhyolite magma at Cordón Caulle, Chile
}

\author{
Jonathan M. Castro, C. Ian Schipper, Sebastian P. Mueller, A.S. Militzer, \\ Alvaro Amigo, Carolina Silva Parejas, Dorrit Jacob
}

\section{- To cite this version:}

Jonathan M. Castro, C. Ian Schipper, Sebastian P. Mueller, A.S. Militzer, Alvaro Amigo, et al.. Storage and eruption of near-liquidus rhyolite magma at Cordón Caulle, Chile. Bulletin of Volcanology, 2013, 75 (702), pp.1-17. 10.1007/s00445-013-0702-9 . insu-00804471

\section{HAL Id: insu-00804471}

https://hal-insu.archives-ouvertes.fr/insu-00804471

Submitted on 28 Mar 2013

HAL is a multi-disciplinary open access archive for the deposit and dissemination of scientific research documents, whether they are published or not. The documents may come from teaching and research institutions in France or abroad, or from public or private research centers.
L'archive ouverte pluridisciplinaire HAL, est destinée au dépôt et à la diffusion de documents scientifiques de niveau recherche, publiés ou non, émanant des établissements d'enseignement et de recherche français ou étrangers, des laboratoires publics ou privés. 
Storage and eruption of near-liquidus rhyolite magma at Cordón Caulle, Chile

Jonathan M. Castro

C. Ian Schipper

Sebastian Mueller

A.S. Militzer

Alvaro Amigo

Carolina Silva Parejas

Dorit Jacob

\section{Abstract}

The last three eruptions at the Cordón Caulle volcanic complex, Chile, have been strikingly similar in that they have started with relatively short pre-eruptive warning and produced chemically homogeneous rhyolite to rhyodacite magma with glassy to aphyric texture. These characteristics collectively call for an understanding of the storage conditions leading to the rapid rise and extraction of crystal-poor silicic magma from volcanoes. We have analyzed and experimentally reproduced the mineral assemblage and crystal chemistry in rhyolite magma produced in the most recent eruption of Cordón Caulle and we use these to infer magma storage and ascent conditions. Fe-Ti oxide mineral geothermometry suggests that the rhyolite was stored at $\sim 870-920^{\circ} \mathrm{C}$. At these temperatures, the phenocryst assemblage (plag $\sim \mathrm{An}_{37}>\mathrm{cpx}+\mathrm{opx}>$ mag+ilm) can be reproduced under $\mathrm{H}_{2} \mathrm{O}$-saturated conditions of between 100 and $50 \mathrm{MPa}$, corresponding to crustal depths between about 2.5 and $5.0 \mathrm{~km}$. The shallow and relatively hot magma storage conditions have implications for the rapid onset, degassing efficiency and progression from explosive to mixed pyroclasticeffusive eruption style at Cordón Caulle.

\section{Introduction}

Forecasting when and how volcanoes erupt is a central goal of volcanology and a problem of great societal importance (Eichelberger 1995). The recent eruption at volcán Chaitén (Lara 2008) has shown that explosive eruptions of rhyolite magma can develop quickly and with little warning, thus hampering efforts to mitigate imminent volcanic hazards. Chaitén demonstrated that rhyolite eruptions follow a temporal pattern, one that is typified by initial Plinian explosions that within days grade into voluminous outpourings of lava and vigorous pyroclastic fountains. Understanding the causes of this eruption transition is critical, as the hybrid lava and ash venting can last for months, 
creating a recurring threat to people living near the volcano, or flying around its ash plume.

The causes of rapid eruptive onsets and transitions in silicic systems are obscure, in part due to the paucity of directly monitored events. Evidence is emerging, however, that the abrupt onset of these eruptions is due to magma being stored shallowly in the crust $(<10 \mathrm{~km})$ and that, despite its high silica content, magma is quite mobile and able to rise to surface in mere hours (Castro and Dingwell 2009). The exceptionally short ( $~ 36$ hrs; Lara 2008) precursory seismic interval at volcán Chaitén in May, 2008, for example, demonstrated the fast transfer of magma from storage through a rapidly emplaced dike-like feeder system rooted in a shallow crustal magma chamber (Wicks et al. 2011). Once the 2008 Chaitén eruption was underway, magma moved to the vent at rates sufficiently fast to preclude significant open-system degassing, which, in turn promoted several days of vigorous pyroclastic activity before lava effusion commenced (Lara 2008).

On 4 June 2011, a remarkably similar eruption sequence occurred at the Puyehue-Cordón Caulle volcanic complex of southern Chile (Lara et al. 2006). This eruption of rhyolitic magma started on the northeastern side of Cordón Caulle after just two days of intense shallow seismicity and, like at Chaitén, initiated with a Plinian phase that produced widespread airfall deposits comprising nearly aphyric pumice and glassy pyroclasts (Fig. 1). Following ten days of explosive activity, which included pyroclastic flows and falls, chemically identical lava began effusing from the same vents as continuing pyroclastic fountain activity (Silva Parejas et al. 2012). 
The eruption of crystal-poor silicic magma, while generally rare, offers a robust glimpse of the chemical and physical characteristics of the ultimate preeruptive magma reservoirs that feed these events. This is because eruption of crystal-poor magma requires: 1) equilibration at near-liquidus conditions, and 2) sufficiently rapid magma ascent such that little or no crystallization (phenocryst or microlite growth) occurred en route to the surface (e.g., Hammer and Rutherford 2002; Castro and Gardner 2008). In the case that the melt is significantly hydrous so as to saturate in a separate $\mathrm{H}_{2} \mathrm{O}$-vapour, then the negatively sloping geometry of melt-crystal phase boundaries in P-T space requires that the magma must either be very hydrous at great depths or very hot at shallow levels (e.g., Coombs and Gardner 2001). As the recent eruption of Cordón Caulle is only the second closely monitored eruption of crystal-poor rhyolite magma, it represents a prime opportunity to learn about the conditions of magma storage, mobilization, and how these initial conditions underpin the observed explosive to effusive course of rhyolite eruptions.

In this paper, we report the geochemical and petrological features of early-erupted pumice, lava and vitreous pyroclasts from Cordón Caulle, and use these data to constrain the pre-eruptive magma storage conditions. We combine the petrologically constrained magma storage conditions with the timing and rates of eruptive activity in order to interpret magma physical properties and transfer behaviour from storage to the eruption.

\section{Sequence of the 2011-2012 eruption of Cordón Caulle}

Prior to its 2011 eruption, the Cordón Caulle was last active in late May, 1960, in a fissure-fed rhyolite eruption that started $\sim 38 \mathrm{hr}$ after, and was 
possibly triggered by, the great $\mathrm{M}_{\mathrm{w}} 9.5$ Valdivia subduction zone earthquake (Lara et al. 2004). The 2011-2012 eruption was a moderate-sized eruption of rhyolitic magma ( VEI 4; Silva Parejas et al. 2012) involving both explosive and effusive phases. The eruption started around 13:00 hrs, 4 June 2011 following approximately 2 months of elevated but broadly distributed seismicity across the 25 km-long Puyehue-Cordón Caulle complex. Just two days before the eruption, on June 2 and 3, shallow (2-6 km) seismicity intensified and became concentrated in the SE sector of Cordón Caulle (Silva Parejas et al. 2012), where the future vent would be. Once underway, the eruption rapidly escalated into a Plinian eruption lasting 2 days. After reaching a maximum altitude of about 14 $\mathrm{km}$, pyroclastic columns oscillated in height $(3-10 \mathrm{~km})$ over the next 7 to 9 days, in response to frequent (up to 10s per minute), variably sized explosions (SERNAGEOMIN/OVDAS bulletin 37 2011). On 12-13 June, pulsating pyroclastic jets were accompanied by oscillating tremor signals and vigorous explosions that cast large ballistic bombs to distances of up to $2.5 \mathrm{~km}$ from the vent (SERNAGEOMIN/OVDAS bulletin 38 2011). After about 10 days of purely pyroclastic and gas-venting activity, lava effusion began from the same vents that continued to fuel pyroclastic fountains (Fig. 1). The lava emerged at high initial fluxes ( 30-80 m³ $\mathrm{sec}^{-1}$; Silva Parejas et al. 2012).

\section{Samples, Analytical and Experimental Methods}

Our expeditions in July 2011 and January 2012 to PCCVC yielded a nearly complete sequence of eruption products. We first collected the Plinian fall deposit at Cardenal-Samoré Pass, on the Chile-Argentine border, roughly $20 \mathrm{~km}$ ESE of the active vent. The deposit at this location represents the earliest- 
erupted material, deposited on 4-5 June 2011 to the ESE by strong upper-level winds. The relationship of this sampling site to the eruption chronology is based on the SE direction of the tephra plume on 5 June 2011, as captured that day by a NASA GEOS satellite (see sample locations in Fig. 1). During the second trip (January 2012) we collected near-vent-facies materials including glassy ballistic bombs (at $\sim 2 \mathrm{~km}$ from vent), ash from the still active pyroclastic jets (also $\sim 2 \mathrm{~km}$ from vent), and two rhyolite blocks from the active lava flow.

At the time of sampling, the Plinian fall deposit at Cardenal-Samoré pass was in primary depositional form with no sign of erosion, likely due to burial by a recent snowfall. This deposit comprises large beige pumice lapilli $(2-6 \mathrm{~cm})$, dense, vitreous glass chips ranging from coarse ash $(\sim 1.3 \mathrm{~mm})$ to fine lapilli $(\sim 5$ $\mathrm{mm})$, and minor ( $<5$ vol.\%) basaltic and andesitic lithic fragments. Geochemical analyses and petrological experiments are based on pumice lapilli fragments and small obsidian chips from this fall deposit. We collected bulk samples $(\sim 2 \mathrm{~kg})$ of the Plinian tephra and five large $(\sim 4 \mathrm{~cm})$ lapilli from four separate stratigraphic horizons (from base to top), and then dried and sieved these materials in the laboratory. We also collected two volcanic bombs $(\sim 20-40 \mathrm{~cm})$ at a distance of approximately $2.5 \mathrm{~km}$ NNW of the active vent. These bombs were probably erupted during the second week of activity when reports (SERNAGEOMIN/OVDAS bulletin 38 2011) and web cameras (Estacion Futangue, 13 June) indicated large (meters) and numerous incandescent blocks being ejected to great distances from the vent. The bombs have 1-cm-thick glassy rinds and frothy pumiceous interiors (Fig. 1d). The two lava samples are from the NE flow front, approximately $2.5 \mathrm{~km}$ from the vent, and consist of two poorly vesicular blocks with crystalline groundmasses and vesicles that are partly in- 
filled with a well faceted $\mathrm{SiO}_{2}$ mineral. At the time of our second sampling mission (January, 2012), the lava had flowed for 8 months, and thus experienced a long cooling and degassing history. This protracted history is manifested in the lava samples' microlite-rich groundmass textures and overgrowth rims on plagioclase and pyroxene phenocrysts (Fig. 2).

All geochemical analyses were performed on powdered aliquots of large Plinian pumice lapilli, and on polished thin-sections of these and dense glassy clasts (e.g., Fig. 2). Polished thin sections were made from epoxy-impregnated samples using standard techniques. We identified the phenocryst mineral assemblage by optical light microscopy (in transmission and reflectance) and by EDS-SEM using an Oxford Link detector mounted to a Zeiss-DSM942 SEM.

Major and minor element compositions of all crystalline phases and glassy groundmasses were determined by EPMA using the JEOL Superprobe at the Institut für Geowissenschaften, University of Mainz. We employed operating conditions similar to those described in Castro and Dingwell (2009). For all of the major elements except $\mathrm{Na}$, we used a focused beam, $15 \mathrm{kV}$, and $8 \mathrm{nA}$ current. Na-analyses were made with a defocused beam $(\sim 10 \mu \mathrm{m})$ and reduced current ( $6 \mathrm{nA})$ and were placed first in the sequence in order to minimize Na-migration. To further mitigate the effects of Na-migration under the electron beam, we performed offline corrections based on the measured decay of $\mathrm{Na}$ counts with time (e.g., Nielson and Sigurdsson, 1983; Devine et al., 1995). Na-decay curves were measured using the same beam conditions as the unknown analyses. We typically analyzed between 5 and 10 separate points per phase. Standardization was based on known compositions of glass and mineral standards. We periodically checked for instrument drift during our analyses of unknowns by re- 
analyzing standards. Despite correcting for Na-loss, low-totals ( 95-97\%) were repeatedly observed in analyses of natural and experimental glasses. We attribute these low major element totals to the presence of dissolved volatiles in the glass, primarily $\mathrm{H}_{2} \mathrm{O}$, which the microprobe does not analyze.

Photomicrographs (100-500 x magnifications) of areas demonstrating experimental textures and mineral habits (e.g., Fig. 2) were collected in backscattered mode (BSE) on the EPMA using a slow (90 sec) scan setting and 12 $\mathrm{KeV}$. We analyzed several BSE images (2-5) of each experiment in order to determine the bulk crystallinity (vol.\%) using Image J software.

Bulk-rock major and trace element contents were determined on 12 pumice lapilli $(3-5 \mathrm{~cm})$ clasts and grouped into three samples of four clasts each. Individual clasts were homogeneous in colour and vesicle texture. The clasts were powdered in an agate mortar, and analyzed using a Phillips MagiXPRO-XRF instrument. Rare-earth and trace element compositions of brown and white pumice domains were also analyzed in situ with laser ablation inductively coupled mass spectrometry (LA-ICP-MS) at the University of Mainz. All analyses were performed on an Agilent 7500ce quadrupole LA-ICP-MS coupled to an esi/New Wave Research NWR193 excimer laser ablation system with 193 nm wavelength. Ablation was carried out with laser energy densities of $5.32 \mathrm{~J} / \mathrm{cm}^{2}$ at $5 \mathrm{~Hz}$ using He gas as a carrier gas. The laser spot size was $35 \mu \mathrm{m}$ for most analyses but was occasionally reduced to $20 \mu \mathrm{m}$ to measure small domains. For data reduction the software GLITER 4.0 (Macquarie University, Sydney, Australia) was used with NIST SRM 610 as external standard and 43Ca (CaO measured by EPMA) was used as internal standard. Data for NIST SRM 610 were 
taken from the GeoReM database (e.g., Jochum and Nehring 2006). For details on detection limits and uncertainties see Jacob (2006).

Small $(\sim 20-120 \mu \mathrm{m})$ glass inclusions (GI) are abundant in plagioclase microphenocrysts in all eruptive products (Fig. 2h). We analyzed 13 of these for their major element and volatile chemistry in order to constrain the pre-eruptive volatile composition of the Cordón Caulle magma. Inclusions were selected primarily on the basis of size and position within the plagioclase phenocryst hosts. Small inclusions $(<50 \mu \mathrm{m})$ located at or near the crystal margin were not considered for analysis. Furthermore, glass inclusions that contained oxide or other types of microlites were not analyzed. All analyzed glass inclusions were vesicle free and isolated from fractures and cleavage planes within the plagioclase hosts. Major elements were measured on glass inclusions by EPMA using the methods described in the previous paragraphs; these EPMA analyses were done after we analyzed the glass inclusions for their $\mathrm{H}_{2} \mathrm{O}$ and $\mathrm{CO}_{2}$ by FTIR. The procedure for exposing and doubly polishing glass inclusions followed closely the method described in Luhr (2001).

The volatile components dissolved in silicate GI were measured by FTIR spectroscopy using a Thermo-Nicolet FTIR bench with attached Continuum series microscope. All analyses were performed in transmission mode on doubly polished glass inclusion wafers. We used between 64 and 512 scans, $4 \mathrm{~cm}^{-1}$ spectral resolution, and collected background spectra every 5 minutes. Because of the typically small size of glass inclusions, we used a 30X objective and square aperture of $50-\mu \mathrm{m}$ breadth. The weight fractions of hydrous species $\left(\mathrm{OH}^{-}\right.$and molecular $\mathrm{H}_{2} \mathrm{O}$ ) were determined from the Beer-Lambert relation, using the calibration of Zhang et al (1997), and using the spectral peaks appearing at 4500 
$\mathrm{cm}^{-1}\left(\mathrm{OH}^{-}\right)$and $5200 \mathrm{~cm}^{-1}$ (molecular $\left.\mathrm{H}_{2} \mathrm{O}\right)$. Glass density was determined by the method of Lange and Carmichael (1990) using the analyzed major element compositions. The $\mathrm{CO}_{2}$ concentration was determined from the height of the absorption peak at $2350 \mathrm{~cm}^{-1}$ utilizing extinction coefficients from both Blank (1993) and Behrens et al (2004). These two calibrations yield different ( 12\%) $\mathrm{CO}_{2}$ contents, and this is the largest source of uncertainty in the assessment of $\mathrm{CO}_{2}$ in GI. GI thickness was determined by way of a Mitutoyo digital micrometer having accuracy of $\pm 2 \mu \mathrm{m}$. Taken together, the errors associated with thickness measurements and extinction coefficients create an average analytical uncertainty of about $10 \%$ of the calculated values.

\section{Petrological experiments}

We carried out a series of constant pressure and temperature experiments in order to constrain the stability fields of the natural phenocrystsilicate glass assemblage erupted as pumice at Cordón Caulle, and from these data, we estimate the pressure and temperatures of pre-eruptive magma storage (e.g., Rutherford et al. 1985; Martel et al. 1998; Coombs and Gardner 2001; Hammer and Rutherford 2003). This approach assumes that the phenocrysts grew predominantly during their residence in the shallow crustal storage chamber, and that they are in equilibrium with the melt (now glass) that contains them. The lack of microlites in the Plinian pumice (Fig. 2) supports this assumption, as it indicates there was very little time for the melt to crystallize during its mobilization and subsequent eruption (e.g., Castro and Dingwell 2009). The euhedral character of the phenocrysts indicates that they were in equilibrium with the surrounding melt (Fig. 2), as does the inclusion of glass 
within those crystals that is identical in composition to the matrix glass (Table 2).

We performed all experiments at the University of Mainz using horizontal tube furnaces and Ni-Co-alloy (Waspaloy) autoclaves that were pressurized by liquid $\mathrm{H}_{2} \mathrm{O}$ and a rotary vein pump. All autoclaves contained a $\mathrm{Ni}$-metal filler rod in the "free space" above the experimental capsule. This configuration prevents convection of the pressurizing fluid and fixes the oxygen fugacity $\left(\mathrm{fO}_{2}\right)$ at about NNO+1 (e.g., Geschwind and Rutherford, 1992). Pressure was monitored by a factory-calibrated Bourdon-tube gauge and with a pressure transducer with digital display. The error in pressure readings was about $\pm 0.5 \mathrm{MPa}$. Temperature was measured using inconel-sheathed K-type thermocouples inserted into a bore in the rear of the autoclave, in addition to an onboard thermocouple in the furnace that measured the temperature at the mid-point of the bomb. Little to no difference in temperature was noted between the bomb center and its end, where the capsule would rest.

The starting material is a finely crushed pumice pyroclast from the Plinian fall deposit. This was the same material on which XRF analyses were performed. Pumice powder ( 50-80 mg) along with enough distilled water (3-6 mg) to saturate the melt in $\mathrm{H}_{2} \mathrm{O}$ at the target pressure and temperature were loaded into Au capsules, weighed, and then welded shut with an acetylene-oxygen torch. Capsules were heated on a hot plate $\left(\sim 120^{\circ} \mathrm{C}\right)$ for about 3 minutes and then reweighed to insure the integrity of welds. Capsules that showed weight loss upon heating and re-weighing were discarded.

We ran experiments for between 24 and 312 hours, depending on the temperature and $\mathrm{P}_{\mathrm{H} 2 \mathrm{O}}$ and the need to preserve the mechanical integrity of the 
autoclaves. The experiments' close approach to the natural equilibrium state was ensured by running experiments for long durations; most were run for more than 3 days ( $72 \mathrm{hr}$ ), which is generally sufficient time to achieve local equilibrium between silicate melt and crystalline rims (Pichavant et al., 2007; Cottrell et al., 1999). In addition, some experiments were run as "reversals" in which hydrous glass, previously equilibrated and quenched at a higher or lower temperature than the targeted conditions, was used as a starting material. Depending on the target conditions these experiments resulted in either crystallization or melting. The mineral and glass contents and compositions of these experiments were analysed and compared to the non-reversal experiments performed at the same target conditions in order to test that equilibrium was met and therefore confirm the positions of the phase stability curves.

Pressure and temperature were checked often and noted to be stable every day. Experiments were quenched by a combination of blasting with compressed air (1-2 minutes) and submersion in a circulating cold-water bath. Afterwards, charges were removed from the autoclave, washed in an ultrasonic bath, and dried before weighing them again to check for leakage during the experiment. Experimental charges were cut open with a razor blade, which then caused the fluid within to fizz out of the cut part. The experimental glasses were then removed from the gold, set in epoxy, and polished for analysis by EPMA according to the methods described in the previous section.

\section{Results: Geochemistry, Texture, and Petrology of the 2011 Cordón Caulle rhyolite}

Magma Chemistry, Texture, and Mineralogy 
Table 1 shows the bulk rock composition of the Cordón Caulle Plinian pumice. The pumice is chemically homogenous rhyolite containing approximately 69.5 wt.\% $\mathrm{SiO}_{2}$ (Fig. 3; Le Bas and Streckeisen, 1991). Major and trace element compositions of the 2011-2012 pumice (Supplementary Table 1) are nearly identical within the range of analytical error to rhyolites erupted from Cordón Caulle in 1960, but deviate slightly from those erupted in 1922 (Gerlach et al. 1988; Singer et al. 2008; Fig. 3b).

Groundmass-glass compositions determined by EPMA and LA-ICP-MS resemble the bulk-rock values, but with slightly higher $\mathrm{SiO}_{2}$ and other major element oxides, which likely reflects the small amount of phenocryst growth that occurred in the magma storage zone (Table 2; Supplementary Table 1). Plagioclase-hosted glass inclusions in pumice and lava samples have similar major element compositions to the groundmass glasses (Table 2); minor offsets in $\mathrm{SiO}_{2}$ and $\mathrm{Al}_{2} \mathrm{O}_{3}$ likely reflect a small amount of post-entrapment crystallization of the plagioclase hosts. Volatile concentrations in these inclusions $(n=13)$ determined by FTIR vary from $\sim 0.74$ to 2.4 wt. $\% \mathrm{H}_{2} \mathrm{O}$ and some contain a minor amount ( $\sim 40-70 \mathrm{ppm})$ of $\mathrm{CO}_{2}$ (Table 2$)$.

As seen in Fig. 2, both the pumiceous pyroclasts and dense vitreous bombs are devoid of groundmass crystals. The opposite is true of the lava samples, which contain up to 40 vol.\% plagioclase (as determined by image analysis), pyroxene, and Fe-Ti oxide microlites (Fig. 2j, k). Two colors of pumice occur in the Plinian deposits (Fig. 2b). These are the volumetrically dominant beige pumice and a lower percentage (5-15\%) of dark brown pumice that forms bands and swirling marble-cake structures in the beige pumice. The colour 
differences arise from iron oxidation state variations in the glass (e.g., Moriizumi et al. 2009; Castro et al. 2009), and are not due to mineralogical or textural variations (G. Klingelhofer, Max Planck Institute, written commun., 2012). As seen in Table 2 and Fig. 3, the major and trace element makeup of the brown and beige pumices are identical within the analytical error, indicating that the two pumice types represent the same original magma batch.

All products erupted during the first two weeks at Cordón Caulle are nearly aphyric, having only $\sim 5$ volume percent phenocrysts (Fig. 2). The phenocryst assemblage is the same in the lava and tephra and comprises the following euhedral phases, in order of decreasing abundance: plagioclase $(\sim 0.5-$ $4 \mathrm{~mm}$ long), orthopyroxene $(\sim 0.5 \mathrm{~mm}-2 \mathrm{~mm})$, clinopyroxene $(\sim 0.5 \mathrm{~mm}-2 \mathrm{~mm})$, magnetite $(\sim 1 \mathrm{~mm})$, and ilmenite $(\sim 1 \mathrm{~mm})$. Accessory phases include apatite and pyrhotite. The crystals often form intergrowth clusters but may also be found separate and enclosed in highly vesicular microlite-free glass (Fig. 2).

The plagioclase phenocrysts contain about 37 mole $\%$ anorthite component (Supplementary Table 2; Fig. 4a). Although we did not detect plagioclase of higher An-contents in natural samples, we did analyze two calcic plagioclase crystals $\left(\sim \mathrm{An}_{60}\right)$ in a phase equilibrium experiment. These rare crystals fall outside the spread of compositions produced in the experiments, suggesting that they are xenocrystic and inherited from the powdered natural pumice starting material. Thus, the natural plagioclase phenocryst assemblage may include some rare Ca-rich plagioclase. Nevertheless, most plagioclase phenocrysts are unzoned, euhedral, and simply twinned with tablet morphologies. Pyroxene occurs as both ortho- and clinopyroxene. These two phases have remarkably constant compositions (Supplementary Table 3) 
plotting either on the Mg-rich side of the enstatite-ferrosilite boundary (opx; En55-59), or just below the diopside-hedenbergite join (cpx; Fig. 4b).

Compositional analyses of 23 touching magnetite-ilmenite pairs are given in Supplemental Table 5. All oxide pairs were found to be in equilibrium according to their $\mathrm{Mg} / \mathrm{Mn}$ ratios and the empirical model of Bacon and Hirschmann (1988). The compositional data were input into the Fe-Ti two-oxide geothermometer of Ghiorso and Evans (2008), which yielded a $\mathrm{T}_{\max }$ of $923^{\circ} \mathrm{C}$, $\mathrm{T}_{\min }$ of $865^{\circ} \mathrm{C}$, and an average equilibration temperature of $896^{\circ} \mathrm{C}$ (s.d. $=15.1^{\circ} \mathrm{C}$ ). The standard deviation about the mean of compositional analyses is less than uncertainty in the model calculation and thus we consider these temperature estimates to be accurate to $\pm 20^{\circ} \mathrm{C}$ (Ghiorso and Evans 2008). As will be shown in the following section, the average temperature falls within the experimentally determined Fe-Ti oxide liquidus at $\mathrm{P}_{\mathrm{H} 20}$ of about $100 \mathrm{MPa}$. Oxygen fugacity values are reduced compared to the Nickel-Nickel Oxide buffer by about 1 log unit, thus positioning it very close to the QFM-buffer assemblage.

Experimental phase petrology

Fig. 5 presents the results of phase equilibrium experiments (see also Table 3). The $\mathrm{H}_{2} \mathrm{O}$-saturated liquidus temperature is $\geq 975^{\circ} \mathrm{C}$ at $50 \mathrm{MPa}$ and $>$ $950^{\circ} \mathrm{C}$ at $200 \mathrm{MPa}$. The first phases to appear with decreasing temperature are Fe-Ti oxides, followed by ortho- and clinopyroxene, plagioclase, and then, for $\mathrm{P}_{\mathrm{H} 20}>100 \mathrm{MPa}$, amphibole (Table 3; Cottrell et al., 1999). A relatively restricted range of conditions favors the formation of the natural phenocryst assemblage in this $\mathrm{P}_{\mathrm{H} 2 \mathrm{O}}-\mathrm{T}$ space. Notably, the natural rhyolite is devoid of amphibole, which 
means that a relatively low pressure $(<100 \mathrm{MPa})$ is required to prevent amphibole growth at the magmatic temperatures needed to stabilize plagioclase and Fe-Ti oxides of the observed compositions. Experimental plagioclase compositions matching those in the natural rhyolite $\left(\sim \mathrm{An}_{37}\right)$, for example, follow the plagioclase liquidus boundary across a $50^{\circ} \mathrm{C}$ interval $\left(\sim 850-900^{\circ} \mathrm{C}\right)$ between the pressures of 100 and 50 MPa (Figs. 4, 5; Supplementary Table 5). Experimental pyroxene compositions are much more scattered than the natural compositions, however they do encompass the range observed in nature (Fig. 4b; Supplemental Table 6). Experimental glass compositions (Table 4) match well the natural matrix and inclusion glass compositions in the $\mathrm{P}_{\mathrm{H} 2 \mathrm{O}}$ interval spanning 50 to $100 \mathrm{MPa}$ at $850-900^{\circ} \mathrm{C}$ (Fig. 6).

Combining the experimental phase petrology results with the equilibration temperatures recorded by iron-titanium oxide compositions $\left(\sim 865-920^{\circ} \mathrm{C}\right)$ shows that the natural phenocrysts could have last equilibrated in the rhyolite melt at $\mathrm{H}_{2} \mathrm{O}$-saturated pressures between 100 and $50 \mathrm{MPa}$ (Fig. 5, 6). These conditions correspond to shallow crustal storage between about 2.5 and 5 $\mathrm{km}$, assuming a lithostatic pressure gradient and approximate confining rock density of $2300 \mathrm{~kg} \mathrm{~m}^{-3}$. At these depths, the magma would contain about 2.6 to 4.5 wt.\% dissolved $\mathrm{H}_{2} \mathrm{O}$ (Moore et al., 1998). These melt- $\mathrm{H}_{2} \mathrm{O}$ contents are higher than the amounts preserved in plagioclase-hosted glass inclusions (Table 2), suggesting that the inclusions, if entrapped during plagioclase phenocryst growth in the storage region, had leaked $\mathrm{H}_{2} \mathrm{O}$ during magma ascent and eruption. A source of uncertainty in the magma storage pressure stems from the possibility that the natural phenocryst assemblage crystallized in the presence of a mixed $\mathrm{H}_{2} \mathrm{O}-\mathrm{CO}_{2}$ vapor, which means the mole fraction of $\mathrm{H}_{2} \mathrm{O}$ in the fluid phase 
( $\mathrm{X}_{\mathrm{H} 2 \mathrm{O} \text {-fluid }}$ ) and the activity $(a)$ of $\mathrm{H}_{2} \mathrm{O}$ in the melt would have been less than unity. As our experiments were performed at water-saturation, ie., $a \mathrm{H}_{2} \mathrm{O}=1$, the preeruptive magma storage pressures inferred from experimental phase relations (Fig. 5) are minimum estimates because the effect of reducing the activity of $\mathrm{H}_{2} \mathrm{O}$ by increasing the $\mathrm{CO}_{2}$ in the melt would be to raise the crystallization temperatures of the individual mineral phases. This means that the total pressures on the system needed to stabilize a mineral of a particular composition would also be higher when $a \mathrm{H}_{2} \mathrm{O}<1$. The presence of small amounts of $\mathrm{CO}_{2}(40-$ $70 \mathrm{ppm}$ ) in some, but not all glass inclusions (Table 2) indicates that $a \mathrm{H}_{2} \mathrm{O}$ could have been less than one. If the maximum $\mathrm{CO}_{2}(\sim 70 \mathrm{ppm})$ is representative of the amount dissolved in the melt at its storage conditions (ie., in equilibrium with 2.6 to $4.5 \mathrm{wt} . \% \mathrm{H}_{2} \mathrm{O}$ ) then $a \mathrm{H} 2 \mathrm{O}$ would have been approximately 0.84 to 0.93 . The amount of liquidus curve rise due to this reduction of $a \mathrm{H}_{2} \mathrm{O}$ is difficult to constrain without performing experiments at $a \mathrm{H}_{2} \mathrm{O}<1$ (e.g., Hammer and Rutherford 2002). However, assuming that liquidus curve displacements scale linearly with $\mathrm{X}_{\mathrm{H} 20 \text {-fluid }}$ and $a \mathrm{H}_{2} \mathrm{O}$ in the melt, the equilibration pressures of natural Cordón Caulle phenocrysts would have been as much as $\sim 15 \%$ higher than the values inferred from $\mathrm{H}_{2} \mathrm{O}$-saturated experiments. This shifts the $\mathrm{P}_{\max }$ of magma storage to about $115 \mathrm{MPa}$ and $\mathrm{P}_{\min }$ to approximately $58 \mathrm{MPa}$. The corresponding crustal magma storage depths are about $6 \mathrm{~km}$ and $2.9 \mathrm{~km}$, respectively. It is important to note that if the glass inclusions have suffered the loss of $\mathrm{CO}_{2}$ in addition to $\mathrm{H}_{2} \mathrm{O}$, then total storage pressures could have been even higher than those estimated here.

\section{Discussion: Magma storage, volcanic unrest, and eruption transitions}


The results of this paired analytical-and-experimental study constrain the ultimate position of magma storage leading to the eruption of Cordón Caulle. As demonstrated in the previous section, the observed natural and experimental phase relationships indicate that the Cordón Caulle magma (Fig. 5) could have been stored across a range of pressures. At the upper end of the permissible pressure scale $(\sim 100 \mathrm{MPa})$, the magma would be relatively $\mathrm{H}_{2} \mathrm{O}$-rich and somewhat cool $\left(\sim 850^{\circ} \mathrm{C}\right)$, whereas at the low-pressure limit $(\sim 50 \mathrm{MPa})$, the magma is drier and considerably hotter $\left(>900^{\circ} \mathrm{C}\right)$. The high temperatures indicated by $\mathrm{Fe}$-Ti oxides $\left(\mathrm{T}_{\mathrm{ave}}=896^{\circ} \mathrm{C}\right)$ in the natural samples strongly suggest that the latter was the case. This information helps interpret a number of preand syn-eruptive phenomena that have heretofore only been observed in realtime at one other active rhyolite system, Volcán Chaitén (Lara 2008). These phenomena include the duration and spatial distribution of precursory seismicity, and the transition from purely pyroclastic activity to simultaneous explosive and effusive behaviour (Castro et al. 2012).

The position at which the magma last resided prior to erupting dictates important temporal parameters that may influence the onset and path of precursory volcanic unrest. Importantly, the length scale of magma transport (ie., the depth to storage), in concert with the magma ascent rate, controls how long periods of pre-eruptive unrest could last. The shallow storage depths $(\sim 2.5-5 \mathrm{~km})$ indicated by our experimental mineral-glass phase relations match the hypocentral depths of several hundred volcano-tectonic and long period earthquakes detected 2 days prior to eruption $(\sim 2-6 \mathrm{~km}$;

SERNAGEOMIN/OVDAS bulletin no. 26 2011). This suggests that over these two preceding days, the preparation of a magma feeding system was underway by 
episodic magma injection and concomitant rock fracturing just before the eruption began (e.g., Chouet 1996; Roman and Cashman 2006; Kilburn and Voight 2006; Wicks et al. 2011).

The rheological properties of magma will control its ability to ascend to the surface through newly opened fractures. Magma rheology is complicated due to magma's multi-phase nature (magma = silicate liquid \pm gas bubbles \pm crystals), and the fact that each phase exerts an influence on bulk viscosity (e.g., Spera 2000). Since the 2011 Cordón Caulle magma was nearly aphyric ( $<5 \%$ phenocrysts) and was microlite-free, crystals would have had little effect on raising the bulk viscosity (Lejeune and Richet 1995; Mueller et al. 2010). Effective magma rheology then is a function of the melt viscosity, which is governed by major element composition, $\mathrm{H}_{2} \mathrm{O}$ content, temperature (Giordano et al. 2008) and bubble content, size, and shear rate (Manga et al. 1998). The presence and deformation of bubbles in the melt can either reduce or increase bulk viscosity (Stein and Spera 1992; Bagdassarov and Dingwell 1992; Lejeune et al. 1999). Estimates for the melt viscosity of the 2011-2012 Cordón Caulle magma at its storage conditions are $\sim 10^{4}-10^{5} \mathrm{~Pa}$ sec, (Giordano et al. 2008 with $\mathrm{T}$ $=896^{\circ} \mathrm{C}$ and $\mathrm{H}_{2} \mathrm{O}=2.5-4.5$ wt \%, expected for $\mathrm{P}_{\mathrm{H} 2 \mathrm{O}}=50-100 \mathrm{MPa}$; Moore et al., 1998), placing the magma in a high capillary number ( $C a>>1$ ) regime (e.g., Rust and Manga 2002; Llewellin and Manga 2005). Under these dynamical conditions, bubbles would have effectively reduced the bulk viscosity as they grew and deformed within the Cordón Caulle magma. In summary, the shallow and hot storage conditions of the Cordón Caulle magma promoted bulk magma viscosities approaching the lowest that can be expected for rhyolite magma under natural conditions. This rheological state, combined with the short transit 
distance from storage to surface played a key role in the abbreviated precursory seismic period just prior to the eruption.

Once the vent had opened and the magma began to erupt explosively, magma moving from the storage zone to the surface had the opportunity to degas its volatiles to the surroundings. The efficiency of magma degassing during ascent may have controlled the progression from early pyroclastic venting to later effusive eruption (e.g., Eichelberger et al. 1986; Eichelberger 1995). The initial, days-long period of explosive activity indicates that early magma degassing was inefficient. Magma degassing efficiency is determined by a competition between the magma ascent (and decompression) rate and the rate at which volatiles can bleed off the rising magma (e.g., Jaupart and Allègre 1991; Woods and Koyaguchi 1994). This balance dictates the amount of degassing before the magma reaches the vent and, if tipped too heavily in favor of the ascent rate (and thus volatile retention), magma will not lose enough volatiles to avoid fragmentation (e.g., Alidibirov and Dingwell 1996; Papale 1999; Cashman et al. 2000). Although it is not known a priori what "threshold" level of ascent rate and amount of degassing would preclude fragmentation, the fact that lava began to effuse after about 10 days of continuous pyroclastic venting establishes a timeframe over which some magma degassed sufficiently to remain coherent upon exiting the vent. This timeframe, coupled with the storage depth helps constrain an ascent rate(s) that fostered the formation of the first lavas at the vent. For example, if parcels of magma that became the first lavas ascended on day one from the maximum pre-eruptive storage depth $(\sim 5 \mathrm{~km})$, and spent the first 10 days of the eruption rising without pause, the average magma rise rate would be about $0.6 \mathrm{~cm} \mathrm{sec}^{-1}$ (ie., rise rate $=$ the vertical distance of $5 \mathrm{~km} \div 10$ 
days). Had the magma begun its journey at $2.5 \mathrm{~km}$, the minimum storage depth implied by experiments (Fig. 5,7$)$, the average rise rate would be halved $(\sim 0.3$ $\mathrm{cm} \mathrm{sec}^{-1}$ ). These estimates are maxima in that faster magma ascent would have prevented degassing sufficient for an effusive eruption. For example, if under faster ascent conditions (ie., > 1.0 $\mathrm{cm} \mathrm{sec}^{-1}$ ) magma was able to degas efficiently, then lava should have appeared sooner in the eruption sequence. It is important to note that these ascent rate estimates are made within the context of $\mathrm{H}_{2} \mathrm{O}$ saturated magma. If as discussed previously, $\mathrm{CO}_{2}$ played a role in stabilizing the phenocryst assemblage to higher effective pressures, then faster magma ascent rates could be possible. The ascent rates at Cordón Caulle are, nonetheless, similar to those estimated for crystal-poor rhyolite eruptions at the Inyo Domes (0.4-1.7 $\mathrm{cm} \mathrm{sec}^{-1}$; Castro and Gardner, 2008) and some intermediate magmas (e.g., Rutherford 2010).

The maximum observed flux of lava $\left(\sim 80 \mathrm{~m}^{3} \mathrm{sec}^{-1}\right.$; Bertin et al. 2012; Silva Parejas et al. 2012) provides an independent check on the ascent rates derived from magma storage position and the eruption chronology. Assuming the most geometrically simple conduit as an end-member case (Fig. 7a), if magma flowed through an upright cylindrical conduit of $5 \mathrm{~km}$ length and $100 \mathrm{~m}$ diameter, the observed early flux of lava $\left(\sim 80 \mathrm{~m}^{3} \mathrm{sec}^{-1}\right)$ implies a maximum vertical ascent speed of $\sim 1.0 \mathrm{~cm} \mathrm{sec}^{-1}$ (ie. rise rate = lava flux $\div$ conduit cross sectional area). The ascent speed would roughly quadruple for a conduit of $50 \mathrm{~m}$ diameter. This calculation is clearly sensitive to the choice of conduit radius and its geometry, which is only an estimate based on the reports of activity. A visual description of the lava flow on 20 June 2011 reports that lava had dimensions of approximately 
$50 \times 100 \mathrm{~m}$ at the point of emergence (SERNAGEOMIN/OVDAS bulletin no. 48 2011).

Despite the uncertainty in vent radius and the initial storage depth, there is good agreement between the ascent rates implied by experimental storage and eruption chronology data, and the observed lava flux at the vent. This means that the production of lava from the initially explosive eruption signaled the arrival of magma batches that had traversed the vertical distance from storage to the vent, and did so sufficiently slowly $\left(<1 \mathrm{~cm} \mathrm{sec}^{-1}\right)$ such that they had time to lose most of their volatiles before erupting. An implication of this finding is that the volatile budget shed from these lava-forming magma parcels must have contributed to the vigor of the preceding Plinian and then contemporaneous subPlinian pyroclastic activity, because those volatiles had to go somewhere (e.g., Taylor et al., 1983). As such, the high intensity of the explosive phases during the first days of the eruption could have been influenced by the incipient effusive activity.

In light of the experimental and observational evidence, it appears that the onset of effusion at Cordón Caulle signaled a reduction in conduit overpressure and concomitant magma deceleration to the critical values necessary to preclude fragmentation. It is important to note, however, that despite lava effusion at Cordón Caulle, pyroclastic fountains continued to emit from the same vent that supplied the lava. This juxtaposed pyroclastic and effusive activity, a pattern also observed at Chaitén from 2008-2009 (Castro et al. 2012), requires that the magma parcels erupted as pyroclasts and lava followed different ascent paths, that is, they rose at different rates and/or travel different distances to the vent. These conditions could be met if magma was supplied by a 
dike (Fig. 7b), as had occurred in the previous two eruptions at Cordón Caulle (ie., in 1922 and 1960; Lara et al. 2004) and at Chaitén in 2008 (Wicks et al. 2011). The pattern of deformation around the current Cordón Caulle vent, including en echelon fracture segments and aligned ground cracks (Fig. 1), is consistent with a shallow dike-like feeder rather than a cylindrical conduit (Fink and Pollard, 1983). Eruption of magma through a single point over a dike creates a flow field comprising both vertical and lateral components (Blake and Fink 1987). This two-dimensional flow field allows magma immediately beneath the vent to rise up quicker (or travel a shorter distance from storage at a given rate) than volumes of magma positioned outboard of the vent (Fig. 7). This rapidly rising magma immediately beneath the vent would become pyroclasts. Magma positioned outboard of the vent, but still along the strike of the dike, will follow more inclined paths to the vent and consequently spend more time in transit from the $5 \mathrm{~km}$ depth before reaching the surface. In this scenario, it is the far-traveled magma that would have lost more gas before emerging and thus would become lava. We envision that in the days leading up to the emergence of lava, the explosively erupting magma, which must have been already filling the dike, provided a permeable environment for effective open-system degassing of deeper and perhaps obliquely ascending magma that would eventually become lava (e.g., Okumura et al., 2013).

\section{Summary and Conclusions}

Petrological aspects of rhyolite at Cordón Caulle were analyzed and experimentally reproduced to gain insight into magma storage and transport conditions of the 2011-2012 eruption. The analytical and experimental data 
indicate that the magma was stored shallowly and at near-liquidus conditions just before erupting explosively. Once mobilized, the stored magma was able to create a viable conduit in a matter of days. The formation of a feeder system created a pattern of seismicity consistent with a storage chamber up to $\sim 5 \mathrm{~km}$ deep. The timing and onset of lava effusion is consistent with relatively slow magma rise $\left(<1 \mathrm{~cm} \mathrm{sec}^{-1}\right)$ from shallow storage-conditions that permitted efficient degassing within the conduit. The months-long period of hybrid activity at Cordón Caulle was likely fuelled by a dike, which allowed simultaneous eruption of variably degassed magmas capable of both explosive and effusive behavior.

\section{Acknowledgements}

The authors thank L.E. Lara of the SERNAGEOMIN for providing logistical support and the GeoEye foundation for the use of a high-resolution satellite photo of the Cordón Caulle vent region. C.I. Schipper acknowledges support from ERC grant 202844 under the European FP7. S. Buhre and N. Groschopf provided helpful analytical support. The authors thank P. Wallace, H. Wright, and an anonymous reviewer for providing thorough and useful comments.

\section{References}

Alidibirov M, Dingwell DB (1996) Magma fragmentation by rapid decompression. Nature 380: 146-148 
Bacon, CR, Hirschmann, MM (1988) Mg/Mn partitioning as a test for equilibrium between coexisting Fe-Ti oxides. Am Mineral 73: 57-61

Bagdassarov NSh, Dingwell DB (1992) A rheological investigation of vesicular rhyolite. J Volcanol Geotherm Res 50: 307-322

Behrens H, Tamic N, Holtz Francois (2004) Determination of the molar absorption coefficient for the infrared absorption band of $\mathrm{CO} 2$ in rhyolitic glasses. Am Mineral 89: 301-306

Bertin D, Amigo A, Lara LE, Orozco G, Silva C (2012) La erupción del Cordón Caulle 2011-2012: Evolución fase efusiva. Congreso Geologico Chileno, Antofagasta

Blake S, Fink JH (1987) The dynamics of magma withdrawal from a density stratified dyke. Earth Plan Sci Lett 85: 516-524

Blank JG (1993) An experimental investigation of the behavior of carbon dioxide in rhyolitic melt. PhD thesis California Institute of Technology, Pasadena

Cashman KV, Sturtevant B, Papale P, Navon O (2000) Magmatic fragmentation, in Sigurdsson, H., ed., Encyclopedia of Volcanoes, San Diego, Academic Press p. 421430 
Castro JM, Schipper CI, Tuffen H (2012) Simultaneous pyroclastic and effusive venting at rhyolite volcanoes: the cases of Puyehue-Cordón Caulle and Chaitén. EGU General Assembly abstracts Vol. 14, EGU2012-7760

Castro JM, Gardner JE (2008) did magma ascent rate control the explosiveeffusive transition at the Inyo volcanic chain, California? Geology 36: 279-282

Castro JM, Dingwell DB (2009) Rapid ascent of rhyolite magma at Chaitén volcano, Chile. Nature 461: 780-784

Castro JM, Cottrell E, Tuffen H, Logan AV, Kelley KA (2009) Spherulite crystallization induces Fe-redox redistribution in silicic melt. Chem Geol 268: $272-280$

Chouet B (1996) Long-period volcano seismicity: its source and use in eruption forecasting. Nature 380: 309-316

Coombs ML, Gardner JE (2001) Shallow-storage conditions for the rhyolite of the 1912 eruption at Novarupta, Alaska. Geology 29: 775-778

Cottrell E, Gardner JE, Rutherford, MJ (1999) Petrologic and experimental evidence for the movement and heating of the pre-eruptive Minoan rhyodacite (Santorini, Greece). Contrib Mineral Petrol 135: 315-331 
Devine, JD, Gardner, JE, Brack, HP, Layne, GD, Rutherford, MJ (1995) Comparison of microanalytical methods for estimating $\mathrm{H}_{2} \mathrm{O}$ contents of silicic volcanic glasses. Am Mineral 80: 319-328

Eichelberger JC, Carrigan CR, Westrich HR, Price RH (1986) Non-explosive silicic volcanism. Nature 323: 598-602

Eichelberger JC (1995) Silicic volcanism: Ascent of viscous magmas from crustal reservoirs. Annu Rev Earth Planet Sci 23: 41-63

Fink JH, Pollard DD (1983) Structural evidence for dikes beneath silicic domes, Medicine Lake Highland Volcano, California. Geology 11: 458-461.

Gerlach DC, Frey FA, Moreno-Roa H, Lopez-Escobar L (1988) Recent volcanism in the Puyehue-Cordón Caulle region, southern Andes, Chile $\left(40.5^{\circ} \mathrm{S}\right)$ : Petrogenesis of evolved lavas. J Petrol 29: 333-382

Geschwind, CH, Rutherford, MJ (1995) Crystallization of microlites during magma ascent: the fluid mechanics of 1980-1986 eruptions at Mount St Helens. Bull Volcanol 57: 356-370.

Geschwind, CH, Rutherford, MJ (1992) Cummingtonite and the evolution of the Mount St. Helens (Washington) magma system; an experimental study. Geology 20: 1011-1014. 
Ghiorso MS, Evans BW (2008) Thermodynamics of rhombohedral oxide solid solutions and a revision of the Fe-Ti two-oxide geothermometer and oxygenbarometer. Am J Sci 308: 957-1039

Giordano D, Russell JK, Dingwell DB (2008) Viscosity of magmatic liquids: A model. Earth Plan Sci Lett 271: 123-134

Hammer JE, Rutherford MJ (2002) An experimental study of the kinetics of decompression-induced crystallization in silicic melt. J Geophys Res 107: $10,1029-10,1053$

Hammer JE, Rutherford MJ (2003) Petrologic indicators of preeruption magma dynamics. Geology 31: 79-82

Jacob DE (2006) High sensitivity analysis of trace element-poor geological reference glasses by laser ablation-inductively coupled plasma-mass spectrometry (LA-ICP-MS). Geostand Geoanal Res 30: 221-235

Jaupart C, Allègre CJ (1991) Gas content, eruption rate and instabilities of eruption regime in silicic volcanoes. Earth Plan Sci Lett 102: 413-429

Kilburn CR, Voight B (2006) Slow rock fracture as eruption precursor at Soufriere Hills volcano, Montseratt. Geophys Res Lett 25: 3665-3668 
Lange RA, Carmichael ISE (1990) Thermodynamic properties of silicate liquids with emphasis on density, thermal expansion and compressibility. In: Russell JK, Nicholls J (eds) Modern methods of igneous petrology; understanding magmatic processes. Rev Mineral 24: 25-64

Lara LE, Naranjo JA, Moreno H (2004) Rhyodacitic fissure eruption in Southern Andes (Cordón Caulle; 40.5 S) after the 1960 (Mw:9.5) Chilean earthquake: a structural interpretation. J Volcanol Geotherm Res 138: 127-138

Lara LE (2008) The 2008 eruption of the Chaitén Volcano, Chile: a preliminary report. Andean Geology 36: 125-129

Lara LE, Moreno H, Naranjo JA, Matthews S, de Arce CP (2006) Magmatic evolution of the Puyehue-Cordón Caulle Volcanic Complex (40 S), Southern Andean Volcanic Zone: From shield to unusual rhyolitic fissure volcanism. J Volcanol Geotherm Res 157: 343-366

Larsen, J (2006) Rhyodacite magma storage conditions prior to the 3430 yBP caldera-forming eruption of Aniakchak volcano, Alaska. Contrib Mineral Petrol 152: $523-540$

Le Bas MJ, Streckeisen AL (1991) The IUGS systematics of igneous rocks. J Geol Soc London 148: 825-833 
Lejeune A-M, Richet P (1995) Rheology of crystal-bearing silicate melts: An experimental study at high viscosities. J Geophys Res 100: 4215-4229

Lejeune A-M, Bottinga Y, Trull TW, Richet P (1999) Rheology of bubble-bearing magmas. Earth Planet Sci Lett 166: 71-84

Llewellin EW, Manga M (2005) Bubble suspension rheology and implications for conduit flow. J Volcanol Geotherm Res 143: 205-217

Luhr J (2001) Glass inclusions and melt volatile contents at Parícutin Volcano, Mexico. Contrib Mineral Pet 142: 261-283

Manga M, Castro J, Cashman KV, Loewenberg M (1998) Rheology of bubblebearing magmas. J Volcanol Geotherm Res 87: 15-28

Martel C, Pichavant M, Bourdier J-L, Traineau H, Holtz F, Scaillet B (1998) Magma storage conditions and control of eruption regime in silicic volcanoes: experimental evidence from Mt. Pelée. Earth Plan Sci Lett 156: 89-99

Moore, G., Vennemann, T. Carmichael, I.S.E. (1998) An empirical model for the solubility of $\mathrm{H}_{2} \mathrm{O}$ in magmas to 3 kilobars. Am Mineral 83: 36-42

Moriizumi M, Nakashima S, Okumura S, Yamanoi Y (2009) Color-change processes of a plinian pumice and experimental constraints of color-change kinetics in air of an obsidian. Bull Volcanol 71: 1-13 
Mueller S, Llewellin EW, Mader HM (2010) The rheology of suspensions of solid particles. Proc R Soc A 466 1201-1228, doi:10.1098/rspa.2009.0445

Newman S, Lowenstern JB (2002) VolatileCalc: A silicate melt- $\mathrm{H}_{2} \mathrm{O}-\mathrm{CO}_{2}$ solution model written in Visual Basic for Excel. Comp Geosci 28: 597-604

Nielsen, CH, Sigurdsson, H (1981) Quantitative methods for electron microprobe analysis of sodium in natural and synthetic glasses. Am Mineral 66: 547-552

Okumura S, Nakamura M, Uesugi K, Nakano T, Fujioka T (2013) Coupled effect of magma degassing and rheology on silcic volcanism. Earth Plan Sci Lett 362: 163-170.

Papale P (1999) Strain-induced magma fragmentation in explosive eruptions, Nature 397: 425-428

Pichavant, M, Costa F, Burgisser A, Scaillet B, Martel C, Poussineau S (2007) Equilibration scales in silicic to intermediate magmas-Implications for experimental studies. J Petrol 48: 1955-1972

Roman DC, Cashman KV (2006) The origin of volcano-tectonic earthquake swarms. Geology 34: 457-460 
Rust AC, Manga M (2002) Effects of bubble deformation on the viscosity of dilute suspensions. J Non-Newton Fluid Mech 104: 53-63

Rutherford MJ (2010) Magma ascent rates. In Putirka, KD and Tepley III, Rev Mineral 69: 241-271.

Rutherford MJ, Sigurdsson H, Carey SN, and Davis AN (1985) The May 18, 1980, eruption of Mount St. Helens, 1, Melt composition and experimental phase equilibria. J Geophys Res 90: 2929-2947

Silva Parejas C, Lara LE, Bertin D, Amigo A, Orozco G (2012) The 2011-2012 eruption of Cordón Caulle volcanoe (Southern Andes): Evolution, crisis management and current hazards. EGU General Assembly abstracts Vol. 14. EGU2012-9382-2

Singer BS, Jicha BR, Harper MA, Naranjo JA, Lara LE, Moreno-Roa H (2008) Eruptive history, geochronology, and magmatic evolution of the Puyehue-Cordón Caulle volcanic complex, Chile. Geol Soc Am Bull 120 599-618

Spera FJ (2000) Physical properties of magma. In: Sigurdsson H, Houghton B, McNutt SR, Rymer H, Stix J (eds) Encyclopedia of Volcanoes. Academic Press, San Diego, pp 171-190

Stein DJ, Spera FJ (1992) Rheology and microstructure of magmatic emulsions Theory and experiments. J Volcanol Geotherm Res 49: 157-174 
Sun S-S, McDonough WF (1989) Chemical and isotopic systematics of oceanic basalts: implications for mantle composition and processes, in Magmatism in the ocean basins, A.D. Saunders and M.J. Norry, Editors. Geol Soc Spec Publ p. 313345

Taylor, BE, Eichelberger, JC, Westrich, HR (1983) Hydrogen isotopic evidence of rhyolitic magma degassing during shallow intrusion and eruption. Nature 306: $541-545$

Wicks C, de la Llera JC, Lara LE, Lowenstern J (2011) The role of dyking and fault control in the rapid onset of eruption at Chaitén volcano, Chile. Nature 478: 374-377

Woods AW, Koyaguchi T (1994) Transitions between explosive and effusive eruptions of silicic magmas. Nature 370: 641-644

Zhang Y, Belcher R, Ihinger PD, Wang L, Xu Z, Newman S (1997) New calibration of infrared measurement of dissolved water in rhyolitic glasses. Geochim Cosmochim Acta 61: 3089-3100 


\section{Figure Captions}

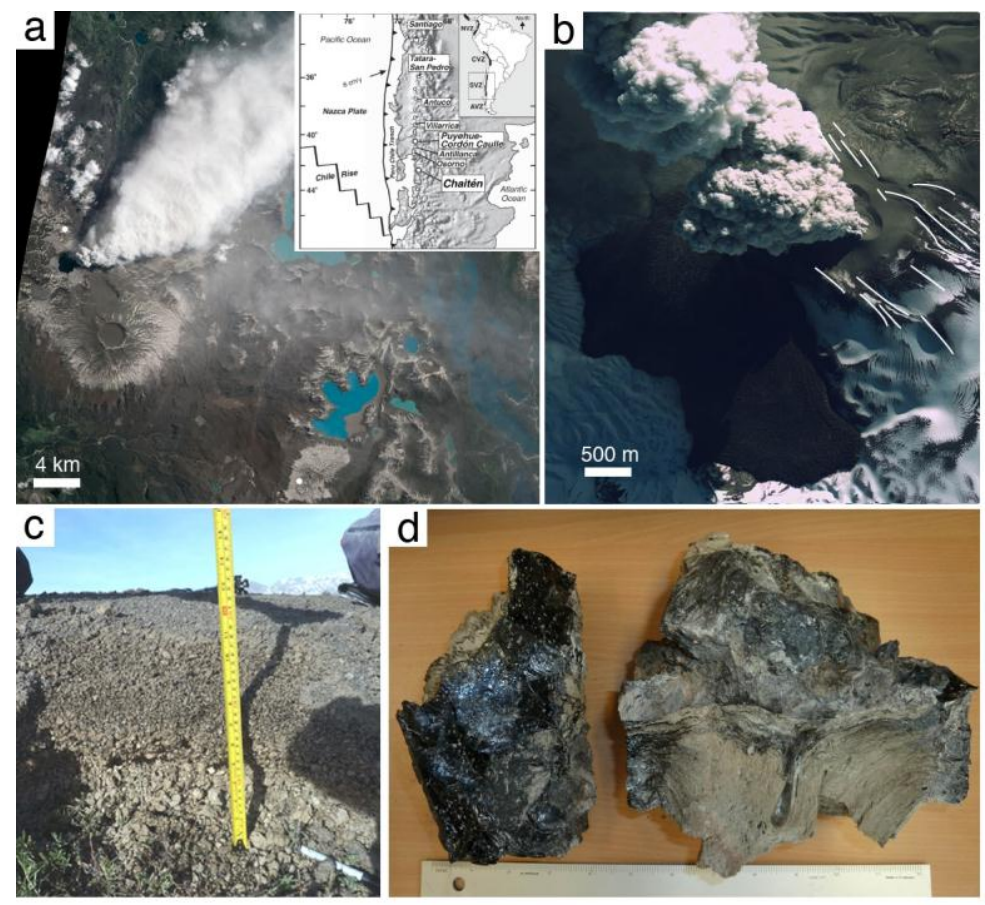

Fig.1., Castro et al.

Fig.1. Cordón Caulle volcano erupting on 4 November 2011 (a; NASA) and on 3 July 2011 (b; Geoeye Foundation Image; North is up). Inset to (a) shows the tectonic setting of the Puyehue-Cordón Caulle Volcanic Complex (after Singer et al. 2008). The lava flow is shown prominently to the west of the pyroclastic plume in frame (b). White dots in frame "a" shows the sample locations for the Plinian fall (center bottom) and near-vent ballistics and lava (upper left). The deformation pattern around the vent (b) comprises several parallel cracks and en echelon fracture segments (bold white lines), consistent with magma supply from a feeder dike (Fink and Pollard, 1983). Frames c and d show representative examples of the early pumice-fall deposit, erupted on 5 June 2011 and glassy bombs collected approximately $2.5 \mathrm{~km}$ from the vent, respectively. 

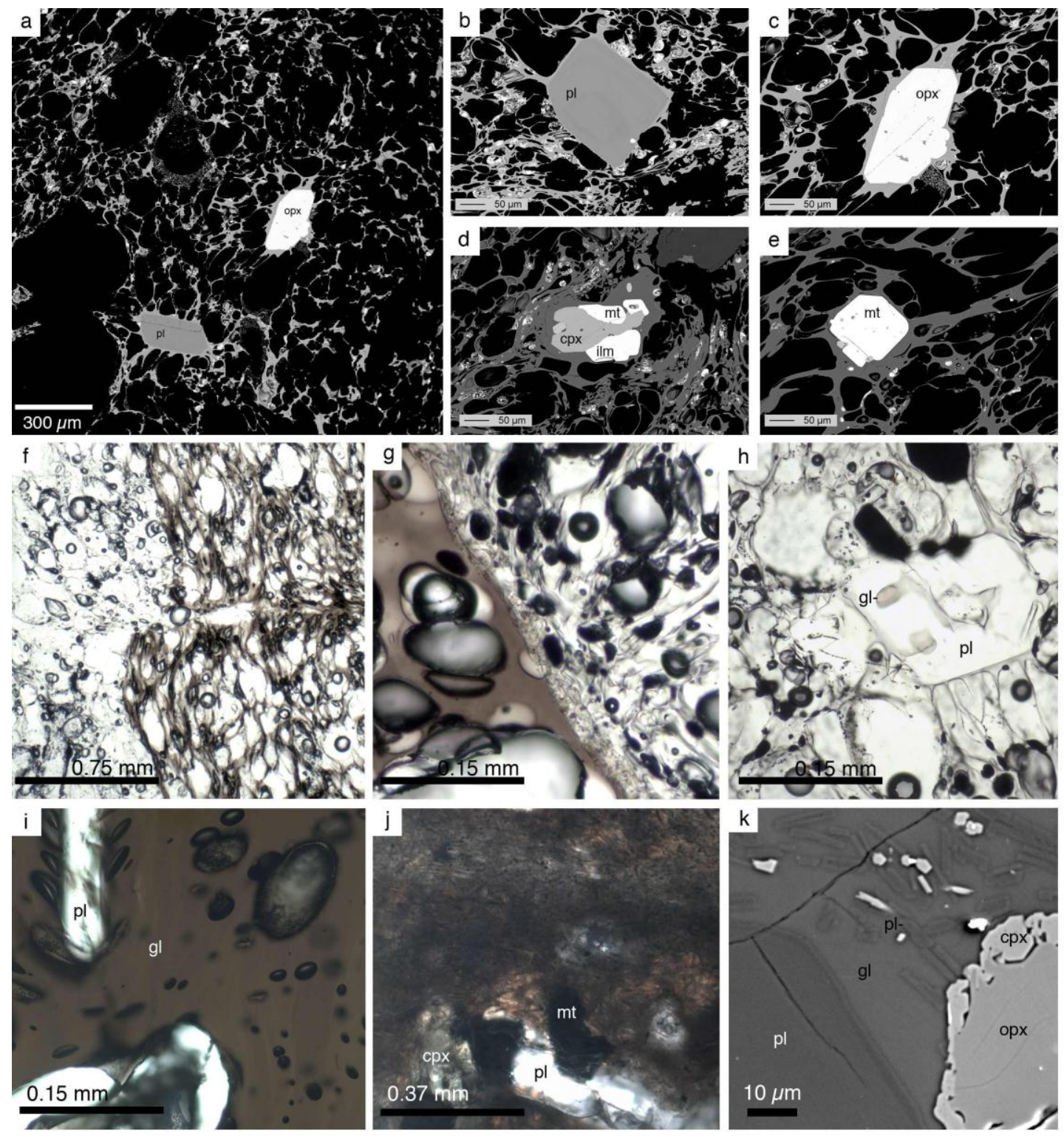

Fig. 2., Castro et al.

Fig. 2. Representative photomicrographs showing the Cordón Caulle rhyolite groundmass texture and phenocryst mineralogy of the early-erupted Plinian pumice collected at Cardenal-Samoré Pass, Chile (a-h), a vitreous bomb (i) from $2.5 \mathrm{~km} \mathrm{NW}$ of vent, and lava sampled from the active flow front $(\mathrm{j}, \mathrm{k})$.

Petrological experiments are based on replicating the mineralogy and chemistry of the phenocryst assemblage in these materials. Images a-e show the typical phenocryst assemblage $(\mathrm{pl}=$ plagioclase, $\mathrm{opx}=$ orthopyroxene, $\mathrm{cpx}=$ clinopyroxene, 
$\mathrm{mt}=$ magnetite, $\mathrm{ilm}=\mathrm{ilmenite}, \mathrm{gl}=$ glass) and a vesicular pumice groundmass glass that is devoid of microlites. Frames f-h show plane light photomicrographs of white and brown pumice domains (f, g) along with close-ups of plagioclasehosted glass inclusions (labeled "gl" in frame h). Glassy bombs (i) and lava erupted in the $2^{\text {nd }}$ week of activity $(\mathrm{j}, \mathrm{k})$ have the same phenocryst assemblage and compositions as the early Plinian pumice, however the lava contains considerably more groundmass crystals and occasional clinopyroxene overgrowth rims on orthopyroxene that are not found in the early erupted pumice.
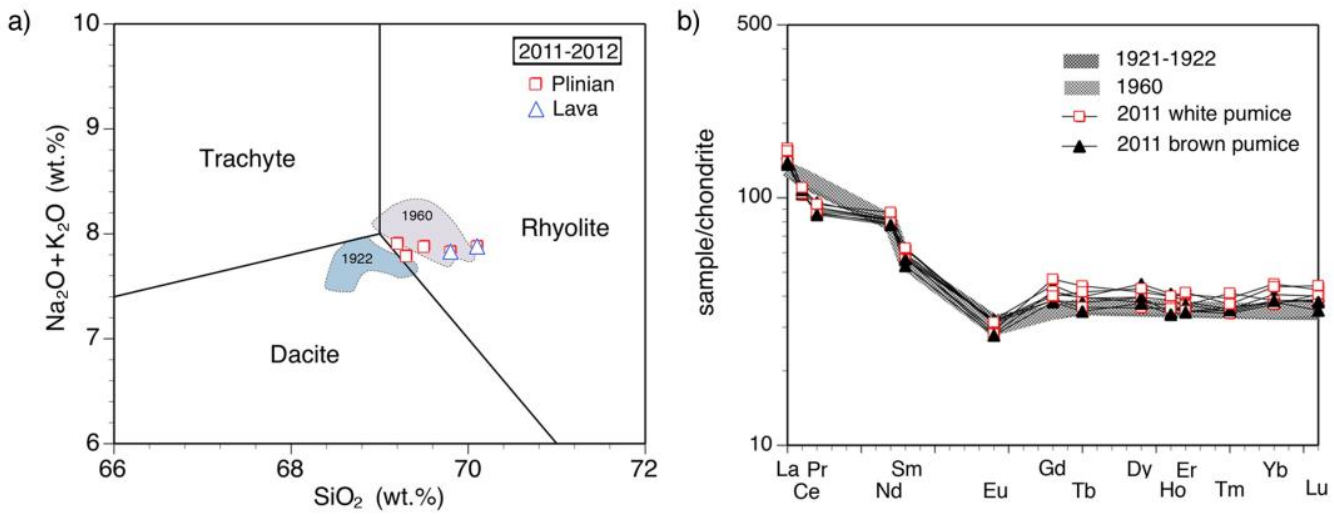

Fig. 3., Castro et al.

Fig. 3. Major-element TAS diagram (a; after Le Bas and Streckeisen, 1991) and chondrite-normalized REE element (b) chemistry of the 2011 Cordón Caulle rhyolite. Squares in frame (a) show Plinian pumice compositions while triangles indicate lavas. The statistical variance of data shown in (a) is smaller than the symbols. Plotted for reference are rock compositions produced during Cordón Caulle eruptions in 1922 and 1960 (data from Gerlach et al. 1988). The close overlap of modern and historical compositions shows that the 2011 eruption tapped nearly identical magma to the previous two documented eruptions. REE 
analytical uncertainty is smaller than the symbols in (b). Chondrite data are from Sun and McDonough (1989).
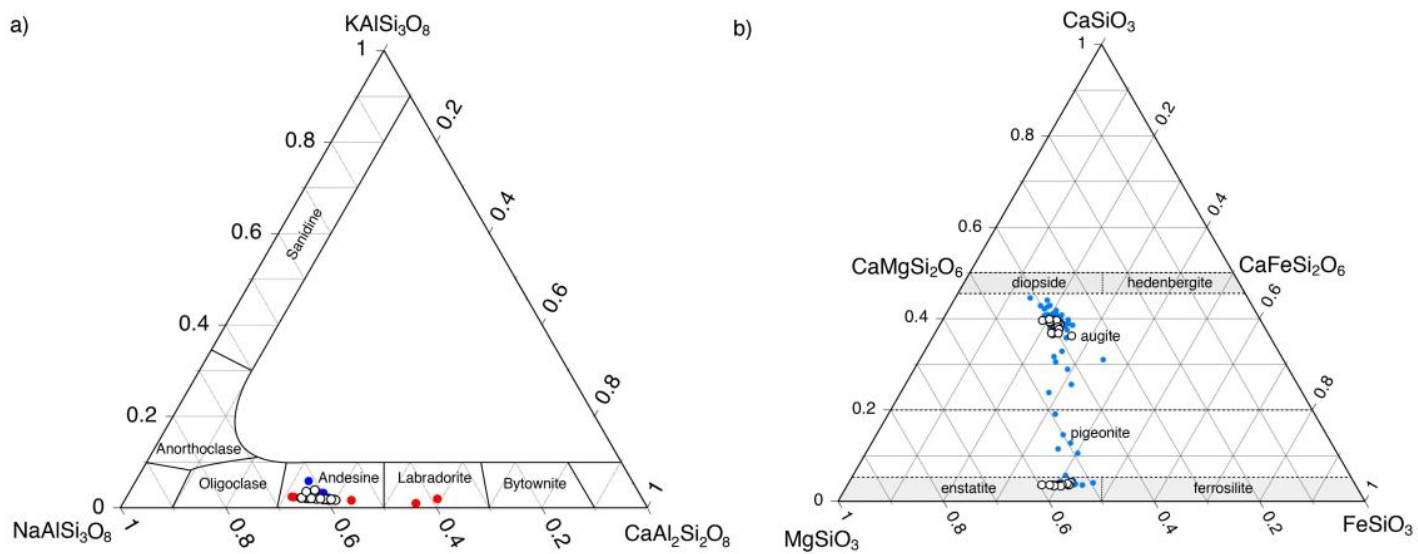

Fig. 4., Castro et al.

Fig. 4. Natural (open circles) and experimental (filled circles) plagioclase (a) and pyroxene (b) compositions found in the Cordón Caulle rhyolite and produced in the lab. In (a), the experimental data cover pressures $\left(\mathrm{P}_{\mathrm{H} 2 \mathrm{O}}\right)$ of 50 (blue circles) and $100 \mathrm{MPa}$ (red circles) across a temperature range of $850-925^{\circ} \mathrm{C}$. In (b), pyroxene compositions in 50 and $100 \mathrm{MPa}$ experiments are grouped together as there was no systematic difference in compositions produced in the two pressure series. The few calcic plagioclase compositions in (a) represent xenocrystic fragments that are found in the natural pumice and were inadvertently incorporated into the starting experimental powders. 


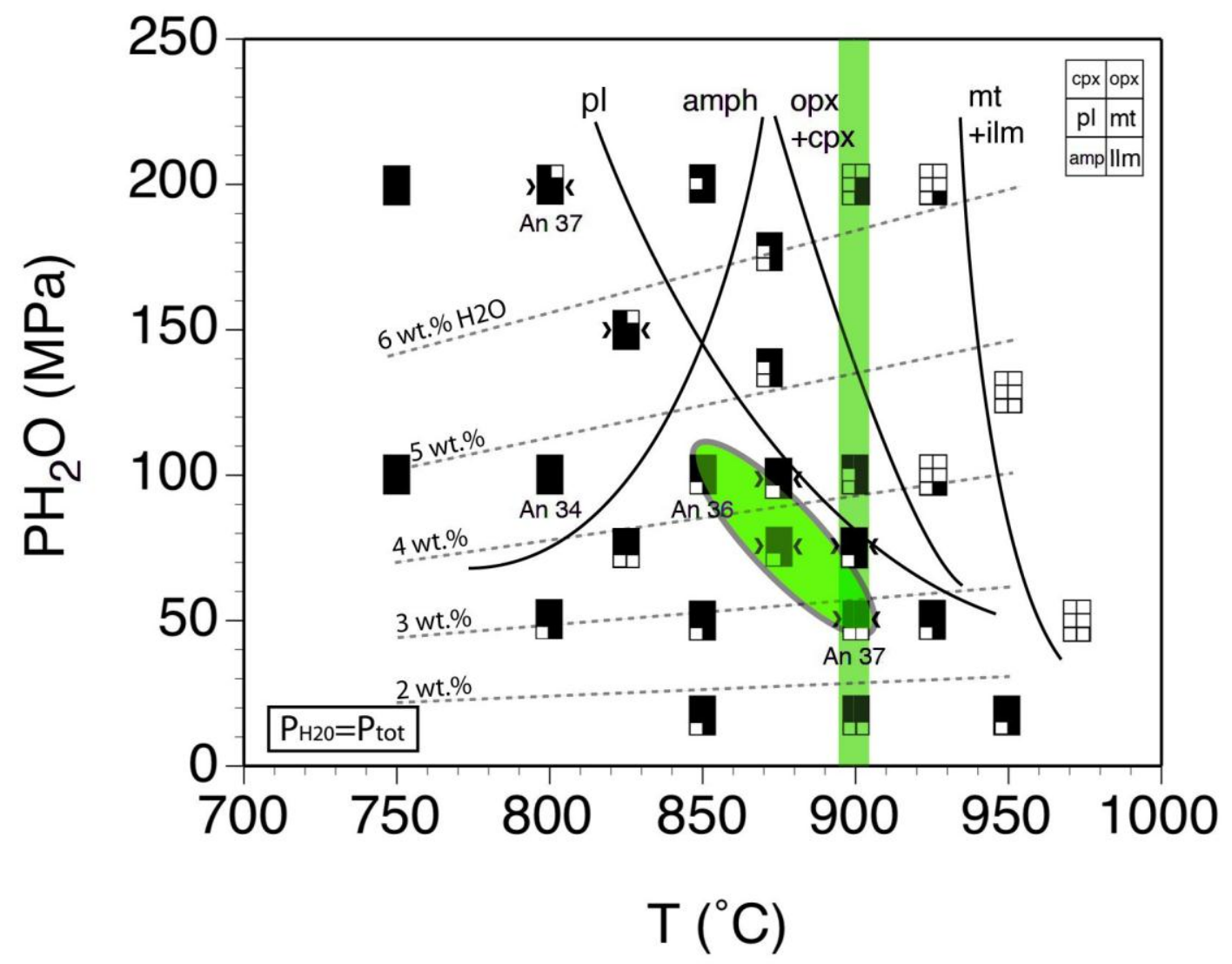

Fig.5., Castro et al

Fig. 5. Phase relations in the Cordón Caulle rhyolite. Each symbol is a separate experiment conducted under $\mathrm{H}_{2} \mathrm{O}$-saturated conditions. Double inward arrows on boxes are duplicate reversal-type experiments. The small sub-squares shown within boxes indicate the mineral phases that grew in the course of the experiment. Curved phase boundaries are mineral-in curves showing the approximate regions of mineral stability with stable phases position to RHS of the curves. The "mag+ilm"-curve demarcates the approximate whole-rock liquidus position. The best match between the natural phase assemblage, mineral compositions ( $\mathrm{An}=$ anorthite contents in plagioclase), and temperatures inferred from Fe-Ti Oxide geothermometry (vertical band at $\sim 900^{\circ} \mathrm{C}$ ) are outlined with an ellipse. These conditions correspond to very shallow crustal 
storage and rather high temperatures for rhyolite magma. The sloping dashed lines show expected concentrations of $\mathrm{H}_{2} \mathrm{O}$ in the silicate melt across a range of pressure and temperature conditions (Moore et al., 1998).
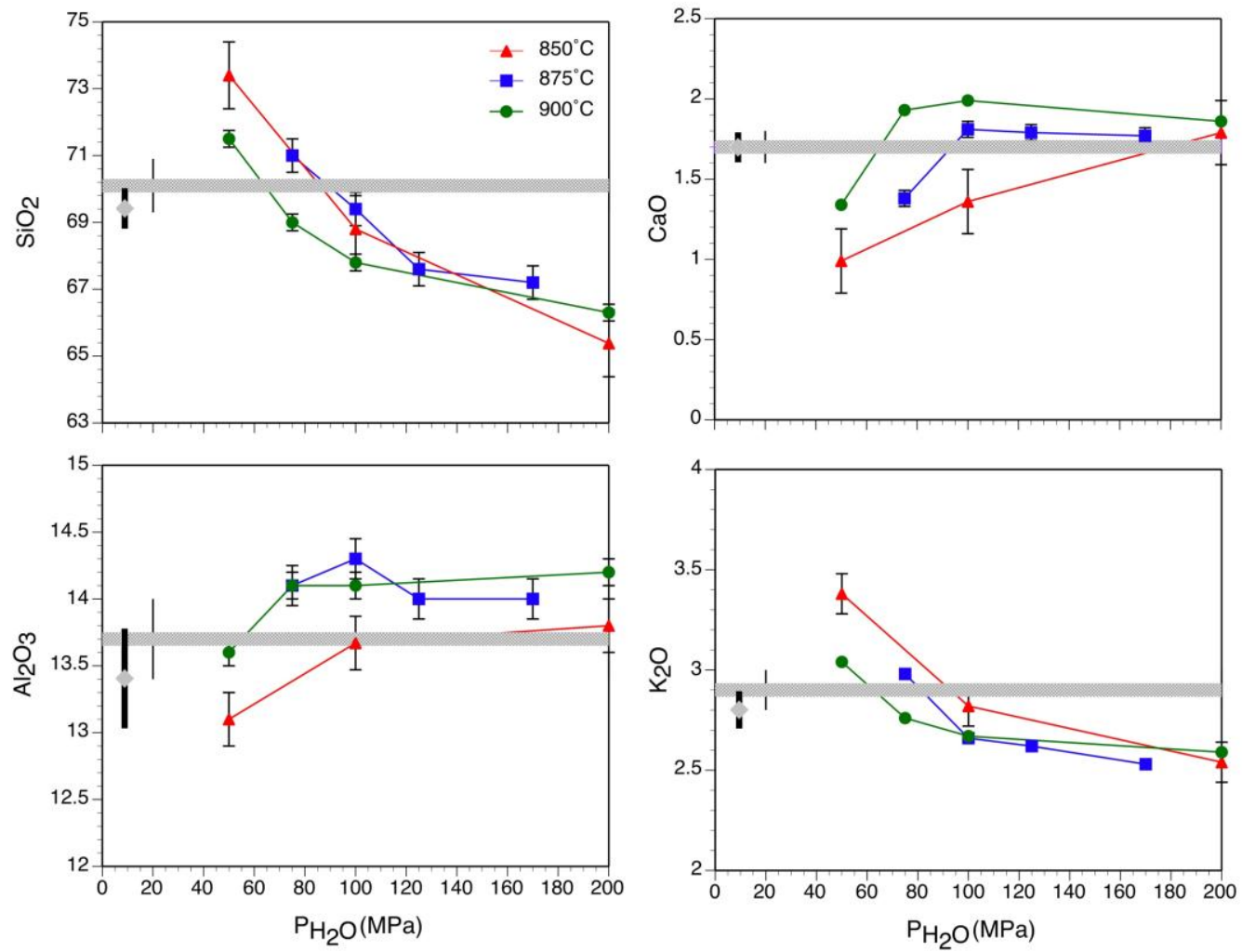

Fig.6., Castro et al

Fig. 6. Cordón Caulle rhyolite experimental glass compositions versus $\mathrm{P}_{\mathrm{H} 2 \mathrm{O}}$ along $850^{\circ} \mathrm{C}$ (triangles), $875^{\circ} \mathrm{C}$ (squares), and $900^{\circ} \mathrm{C}$ (circles) isotherms. Error bars on experimental data show the 1-sigma standard deviation about the mean value. The grey horizontal bar in each frame indicates the average composition of the Plinian pumice groundmass glass and the thin-vertical black line the standard deviation about the mean. Glass inclusion compositions are shown with grey 
diamonds on the LHS, with adjoined thick-vertical black lines indicating the 1sigma standard deviation about the mean. A close correspondence between natural and experimental glass compositions, evident where the experiment and natural data cross, is observed across $\mathrm{P}_{\mathrm{H} 2 \mathrm{O}}$ range of $\sim 50$ to $10 \mathrm{MPa}$.

a)

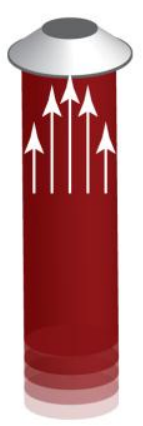

b)

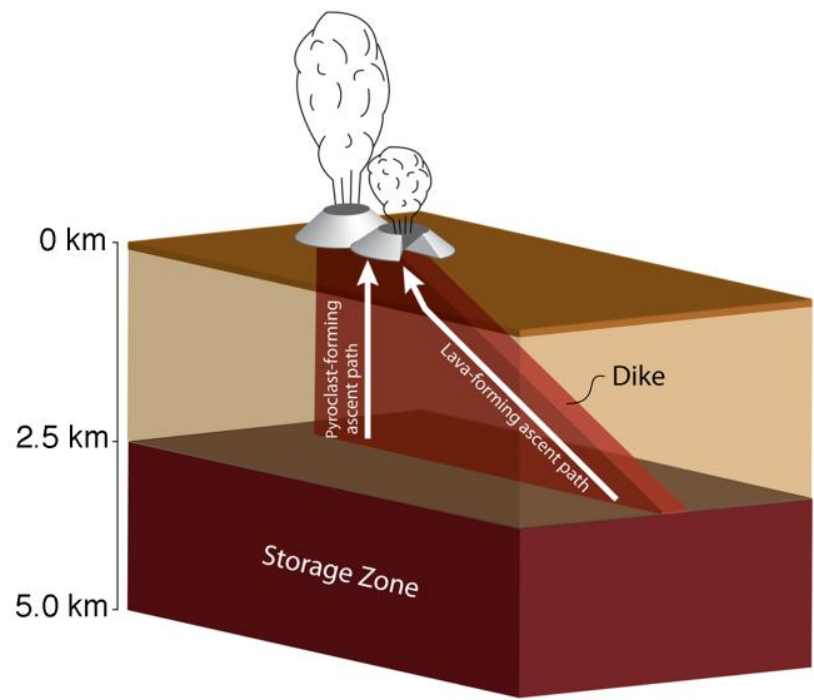

Fig.7., Castro et al

Fig. 7. Conceptual models of magma feeder geometries and ascent paths driving eruptions at Cordón Caulle. In frames a) and b) a dike-feeder conduit (not to scale). In each case, magma ascent velocities are expected to vary as a function of position, however, they are more extreme in the dike (b; see also Blake and Fink, 1987). The 2D flow field in the dike allows magma immediately beneath the vent(s) to travel a relatively shorter distance from storage to the vent than magma outboard of the vent and consequently spend less time in the conduit. Magma flowing inclined paths to the vent will experience longer transit and residence times and therefore may have more opportunity to degas its volatiles 
on the way up. Hybrid pyroclastic and effusive activity may manifest these ascent path variations within dikes. Frame b) also summarizes the magma storage and transport conditions at Cordón Caulle and shows the range of permissible magma storage depths $(2.5-5 \mathrm{~km})$ and distinct paths followed by magma within a dike-like feeder to the surface. According to this model, early explosive activity (ie., the first week) could reflect the progressive drainage of the emplaced feeder dike. Subsequent activity and the shift to hybrid pyroclastic-effusive eruptions may be governed by ascent path and rate variations set up by 2D flow within the dike. 
Table 1

Puyehue-Cordon Caulle Plinian pumice and lava major and trace element compositions determined by XRF

\begin{tabular}{|c|c|c|c|c|c|c|c|c|c|c|c|c|c|c|c|c|c|c|c|c|c|c|c|c|c|c|}
\hline \begin{tabular}{|l|} 
Sam \\
ple
\end{tabular} & $\begin{array}{l}\mathbf{S i} \\
\mathbf{O}_{2}\end{array}$ & \begin{tabular}{|l|}
$\mathbf{T i}$ \\
$\mathbf{O}_{2}$
\end{tabular} & \begin{tabular}{|l|}
$\mathbf{A l}_{2}$ \\
$\mathbf{O}_{3}$
\end{tabular} & $\begin{array}{c}\mathrm{Fe}_{2} \mathbf{O} \\
3(\mathbf{t})\end{array}$ & \begin{tabular}{|c|} 
Mn \\
O
\end{tabular} & \begin{tabular}{|c|} 
Mg \\
O
\end{tabular} & \begin{tabular}{|c|}
$\mathbf{C a}$ \\
$\mathrm{O}$
\end{tabular} & \begin{tabular}{|c|}
$\mathrm{Na}_{2}$ \\
$\mathbf{O}$
\end{tabular} & \begin{tabular}{|l|}
$\mathbf{K}_{\mathbf{2}}$ \\
$\mathbf{O}$
\end{tabular} & \begin{tabular}{|l|}
$\mathbf{P}_{2}$ \\
$\mathbf{O}_{5}$
\end{tabular} & \begin{tabular}{|c|}
$\mathbf{L}$ \\
$\mathbf{O I}$
\end{tabular} & $\begin{array}{l}\text { Tot } \\
\text { al }^{\mathbf{b}}\end{array}$ & Sc & $\mathbf{V}$ & \begin{tabular}{|l|}
$\mathbf{C}$ \\
$\mathbf{r}$
\end{tabular} & \begin{tabular}{|l|}
$\mathbf{C}$ \\
$\mathbf{0}$
\end{tabular} & $\begin{array}{c}\mathbf{N} \\
\mathbf{i}\end{array}$ & $\begin{array}{l}\mathbf{C} \\
\mathbf{u}\end{array}$ & \begin{tabular}{|l|}
$\mathbf{Z}$ \\
$\mathbf{n}$
\end{tabular} & \begin{tabular}{|c|c} 
G & I \\
$\mathbf{a}$ & $\mathbf{I}$ \\
\end{tabular} & \begin{tabular}{l|l}
$\mathbf{R}$ & \\
$\mathbf{b}$ & $\mathbf{S}$ \\
\end{tabular} & Sr & $\mathbf{Y}$ & \begin{tabular}{c|l}
$\mathbf{Z}$ & $\mathrm{I}$ \\
$\mathbf{r}$ & $\mathrm{I}$
\end{tabular} & $\begin{array}{l}\mathbf{N} \\
\mathbf{b}\end{array}$ & Ba \\
\hline \multicolumn{27}{|c|}{ Major elements (wt.\%) ${ }^{\mathrm{a}}$} \\
\hline $\begin{array}{l}\text { Puy- } \\
\text { A }\end{array}$ & $\begin{array}{l}69 . \\
5\end{array}$ & $\begin{array}{l}0.6 \\
6\end{array}$ & $\begin{array}{l}14 . \\
2\end{array}$ & 4.43 & \begin{tabular}{|l|}
0.1 \\
1
\end{tabular} & \begin{tabular}{|l|}
0.5 \\
0
\end{tabular} & \begin{tabular}{|l|}
2.1 \\
8
\end{tabular} & \begin{tabular}{|l|}
5.1 \\
1
\end{tabular} & \begin{tabular}{|l|}
2.7 \\
7
\end{tabular} & \begin{tabular}{|l|}
0.1 \\
1
\end{tabular} & \begin{tabular}{|l|}
0.3 \\
9
\end{tabular} & \begin{tabular}{|l|}
100. \\
1
\end{tabular} & & & & & & & & & & & & & & \\
\hline \begin{tabular}{|l} 
Puy- \\
B
\end{tabular} & $\begin{array}{l}69 . \\
3\end{array}$ & $\begin{array}{l}0.6 \\
9\end{array}$ & \begin{tabular}{|l}
4. \\
3
\end{tabular} & 4.54 & $\begin{array}{l}0.1 \\
1\end{array}$ & $\begin{array}{l}0.5 \\
4\end{array}$ & \begin{tabular}{|l|}
2.2 \\
4
\end{tabular} & \begin{tabular}{|l|}
5.0 \\
7
\end{tabular} & \begin{tabular}{l|}
2.7 \\
2
\end{tabular} & $\begin{array}{l}0.1 \\
2\end{array}$ & $\begin{array}{l}0.3 \\
5\end{array}$ & $\begin{array}{l}100 . \\
3\end{array}$ & & & & & & & & & & & & & & \\
\hline $\begin{array}{l}\text { Puy- } \\
\text { C }\end{array}$ & $\begin{array}{l}69 . \\
2\end{array}$ & $\begin{array}{l}0.7 \\
2\end{array}$ & $\begin{array}{l}14 . \\
2\end{array}$ & 4.65 & $\begin{array}{l}0.1 \\
2\end{array}$ & $\begin{array}{l}0.5 \\
9\end{array}$ & \begin{tabular}{|l|}
2.2 \\
3
\end{tabular} & \begin{tabular}{|l|}
5.1 \\
8 \\
\end{tabular} & \begin{tabular}{|l|}
2.7 \\
2
\end{tabular} & $\begin{array}{ll}0.1 \\
1\end{array}$ & $\begin{array}{l}0.2 \\
7\end{array}$ & $\begin{array}{ll}100 . \\
7\end{array}$ & & & & & & & & & & & & & & \\
\hline $\begin{array}{l}\text { Lava- } \\
\text { A }\end{array}$ & $\begin{array}{l}70 . \\
1\end{array}$ & \begin{tabular}{|l|}
0.7 \\
0
\end{tabular} & $\begin{array}{l}14 . \\
3\end{array}$ & 4.60 & \begin{tabular}{|l|}
0.1 \\
2
\end{tabular} & \begin{tabular}{|l|}
0.5 \\
3
\end{tabular} & \begin{tabular}{|l|}
2.2 \\
2
\end{tabular} & \begin{tabular}{|l|}
5.1 \\
2
\end{tabular} & \begin{tabular}{|l|}
2.7 \\
6
\end{tabular} & \begin{tabular}{|l|}
0.1 \\
2
\end{tabular} & $\mid$\begin{tabular}{l|}
0.2 \\
1
\end{tabular} & \begin{tabular}{|l|}
100. \\
8
\end{tabular} & & & & & & & & & & & & & & \\
\hline \begin{tabular}{|l} 
Lava- \\
B
\end{tabular} & $\begin{array}{l}69 . \\
8\end{array}$ & \begin{tabular}{|l|}
0.7 \\
0
\end{tabular} & $\begin{array}{l}14 . \\
4\end{array}$ & 4.73 & \begin{tabular}{|l}
0.1 \\
2
\end{tabular} & \begin{tabular}{|l|}
0.5 \\
7
\end{tabular} & \begin{tabular}{|l|}
2.3 \\
6
\end{tabular} & \begin{tabular}{|l|}
5.1 \\
4
\end{tabular} & \begin{tabular}{|l|}
2.6 \\
9
\end{tabular} & \begin{tabular}{|l|}
0.1 \\
2
\end{tabular} & $\mid \begin{array}{l}0.1 \\
5\end{array}$ & $\begin{array}{l}100 . \\
8\end{array}$ & & & & & & & & & & & & & & \\
\hline \begin{tabular}{|l|} 
Aver \\
age
\end{tabular} & $\begin{array}{l}69 . \\
6\end{array}$ & \begin{tabular}{|l|}
0.7 \\
0
\end{tabular} & $\begin{array}{l}14 . \\
3\end{array}$ & 4.56 & \begin{tabular}{|l|}
0.1 \\
1
\end{tabular} & $\begin{array}{l}0.5 \\
4\end{array}$ & \begin{tabular}{|l|}
2.2 \\
3
\end{tabular} & \begin{tabular}{|l|}
5.1 \\
4
\end{tabular} & $\begin{array}{l}2.7 \\
5\end{array}$ & \begin{tabular}{|l|}
0.1 \\
1
\end{tabular} & $\begin{array}{l}0.3 \\
4\end{array}$ & $\begin{array}{l}100 . \\
4\end{array}$ & & & & & & & & & & & & & & \\
\hline SD & $\begin{array}{l}0.0 \\
5\end{array}$ & \begin{tabular}{|l}
0.0 \\
3
\end{tabular} & $\begin{array}{l}0.0 \\
6\end{array}$ & 0.12 & $\begin{array}{l}0.0 \\
1\end{array}$ & $\begin{array}{l}0.0 \\
5\end{array}$ & $\begin{array}{l}0.0 \\
4\end{array}$ & \begin{tabular}{|l|}
0.0 \\
7
\end{tabular} & $\begin{array}{l}0.0 \\
2\end{array}$ & $\begin{array}{ll}0.0 \\
1\end{array}$ & $\left|\begin{array}{l}0.0 \\
6\end{array}\right|$ & 0.28 & & & & & & & & & & & & & & \\
\hline \multicolumn{27}{|c|}{ Trace elements (ppm) } \\
\hline $\begin{array}{l}\text { Puy- } \\
\text { A }\end{array}$ & & & & & & & & & & & & & 12 & 15 & 7 & 6 & 2 & 17 & 84 & \begin{tabular}{|l|l}
1 & 7 \\
8 & 7
\end{tabular} & 711 & 1595 & 52 & \begin{tabular}{|l|l|}
33 & \\
0 & 1 \\
\end{tabular} & 11 & 714 \\
\hline $\begin{array}{l}\text { Puy- } \\
\text { B }\end{array}$ & & & & & & & & & & & & & 13 & 13 & 8 & 5 & 3 & 18 & 84 & \begin{tabular}{|l|l}
1 & 7 \\
9 & 7
\end{tabular} & \begin{tabular}{l|l}
70 & 1
\end{tabular} & 1675 & 52 & \begin{tabular}{|l|l|}
32 & \\
8 & 1 \\
\end{tabular} & 10 & 709 \\
\hline $\begin{array}{l}\text { Puy- } \\
\text { C }\end{array}$ & & & & & & & & & & & & & 13 & 13 & 5 & 5 & 2 & 17 & 83 & \begin{tabular}{|l|l|}
1 & 7 \\
7 & 7 \\
\end{tabular} & \begin{tabular}{l|l}
70 & 1
\end{tabular} & 1645 & 51 & \begin{tabular}{|l|l|l|}
32 & 1 \\
6 & \\
\end{tabular} & 10 & 683 \\
\hline \begin{tabular}{|l} 
Lava- \\
A
\end{tabular} & & & & & & & & & & & & & 11 & 7 & 9 & 4 & 5 & 16 & 81 & \begin{tabular}{|l|l}
1 & 7 \\
8 & 7
\end{tabular} & 721 & 1595 & 51 & \begin{tabular}{|l|}
32 \\
8
\end{tabular} & 10 & 681 \\
\hline \begin{tabular}{|l|}
$\begin{array}{l}\text { Aver } \\
\text { age }\end{array}$ \\
\end{tabular} & & & & & & & & & & & & & \begin{tabular}{|l|}
12 \\
.7
\end{tabular} & \begin{tabular}{|l|}
13 \\
.7 \\
\end{tabular} & $\begin{array}{l}6 . \\
7\end{array}$ & \begin{tabular}{|l|}
5. \\
3
\end{tabular} & \begin{tabular}{|l|}
2. \\
3
\end{tabular} & $\begin{array}{l}17 \\
.3 \\
\end{array}$ & \begin{tabular}{|l|}
83 \\
.7 \\
\end{tabular} & \begin{tabular}{|l|l}
1 & 7 \\
8
\end{tabular} & \begin{tabular}{l|l}
70 & 1 \\
.3 & .3 \\
\end{tabular} & $\begin{array}{ll}163 \\
.3\end{array}$ & \begin{tabular}{|l|}
51 \\
.7 \\
\end{tabular} & \begin{tabular}{|l|l}
32 & 1 \\
8
\end{tabular} & \begin{tabular}{|l|}
10 \\
.3
\end{tabular} & \begin{tabular}{|l}
702 \\
.0
\end{tabular} \\
\hline SD & & & & & & & & & & & & & $\begin{array}{l}0 . \\
6\end{array}$ & \begin{tabular}{|l|}
1. \\
2
\end{tabular} & $\begin{array}{l}1 . \\
5\end{array}$ & \begin{tabular}{|l|}
0. \\
6
\end{tabular} & \begin{tabular}{|l|}
0. \\
6
\end{tabular} & $\begin{array}{ll}0 . & 0 \\
6 & 6\end{array}$ & \begin{tabular}{|l|}
0. \\
6 \\
\end{tabular} & 10 & \begin{tabular}{l|l}
0. & 4 \\
6 & 4
\end{tabular} & 4.0 & \begin{tabular}{l|}
0. \\
6
\end{tabular} & 2 & \begin{tabular}{|l|}
0. \\
6 \\
\end{tabular} & $\begin{array}{l}16 . \\
6\end{array}$ \\
\hline
\end{tabular}


Table 2

The 2011 Puyehue-Cordon Caulle matrix glass and plagioclase-hosted glass inclusion major element compositions as determined by EPMA

\begin{tabular}{|c|c|c|c|c|c|c|c|c|c|c|c|c|c|c|c|c|}
\hline Sample & $\mathrm{SiO}_{\mathrm{a}}$ & $\mathrm{TiO}_{2}$ & $\mathrm{Al}_{2} \mathrm{O}_{3}$ & $\mathrm{FeO}$ & MnO & MgO & $\mathrm{CaO}$ & $\mathrm{Na}_{2} \mathrm{O}$ & $\mathbf{K}_{2} \mathbf{O}$ & Cl & $\mathbf{P}_{2} \mathbf{O}_{5}$ & $\mathrm{SO}_{3}$ & Total $^{\text {b }}$ & $\mathbf{O H}$ & $\mathbf{H}_{2} \mathbf{O}^{\mathbf{c}}$ & $\begin{array}{l}\mathrm{CO}_{2} \\
(\mathrm{ppm})^{\mathrm{d}}\end{array}$ \\
\hline \multicolumn{17}{|c|}{ Matrix glasses Plinian } \\
\hline \multirow{2}{*}{ A-gr8 $(n=4)$} & 72.9 & 0.57 & 14.4 & 3.45 & 0.12 & 0.45 & 1.63 & 3.21 & 2.97 & 0.180 & 0.11 & 0.000 & 96.7 & & & \\
\hline & 0.3 & 0.01 & 0.1 & 0.10 & 0.005 & 0.036 & 0.08 & 0.97 & 0.06 & 0.003 & 0.04 & 0.000 & 0.9 & & & \\
\hline \multirow{2}{*}{ A-gr12 (n=4) } & 72.8 & 0.51 & 14.1 & 3.33 & 0.13 & 0.34 & 1.40 & 3.94 & 3.10 & 0.197 & 0.07 & 0.015 & 97.1 & & & \\
\hline & 0.5 & 0.04 & 0.0 & 0.19 & 0.028 & 0.005 & 0.05 & 0.09 & 0.08 & 0.012 & 0.02 & 0.012 & 0.8 & & & \\
\hline \multirow{2}{*}{ A-gr14 (n=2) } & 72.7 & 0.55 & 14.1 & 3.31 & 0.08 & 0.36 & 1.44 & 3.73 & 3.04 & 0.193 & 0.08 & 0.022 & 96.7 & & & \\
\hline & 0.2 & 0.07 & 0.1 & 0.20 & 0.008 & 0.006 & 0.01 & 0.03 & 0.05 & 0.005 & 0.06 & 0.001 & 0.1 & & & \\
\hline \multirow{2}{*}{$\begin{array}{l}\text { B-gr1 (glassy } \\
\text { bomb; } n=5 \text { ) }\end{array}$} & 72.1 & 0.62 & 14.5 & 3.51 & 0.12 & 0.48 & 1.67 & 3.70 & 3.05 & 0.139 & 0.13 & 0.008 & 97.6 & & & \\
\hline & 0.2 & 0.04 & 0.0 & 0.23 & 0.034 & 0.044 & 0.09 & 0.14 & 0.07 & 0.011 & 0.05 & 0.010 & 0.3 & & & \\
\hline \multirow{2}{*}{$\begin{array}{l}\text { B-gr2 (glassy } \\
\text { bomb; } n=3 \text { ) }\end{array}$} & 70.3 & 0.62 & 14.1 & 3.57 & 0.149 & 0.541 & 1.79 & 3.59 & 2.79 & 0.147 & 0.10 & 0.007 & 97.7 & & & \\
\hline & 0.1 & 0.04 & 0.1 & 0.08 & 0.015 & 0.014 & 0.03 & 0.06 & 0.01 & 0.011 & 0.02 & 0.006 & 0.2 & & & \\
\hline \multirow{2}{*}{ B-gr3 $(n=5)$} & 71.9 & 0.63 & 14.4 & 3.66 & 0.15 & 0.55 & 1.84 & 3.68 & 2.86 & 0.150 & 0.10 & 0.007 & 98.4 & & & \\
\hline & 1.0 & 0.05 & 0.3 & 0.97 & 0.062 & 0.196 & 0.24 & 0.77 & 0.73 & 0.045 & 0.012 & 0.010 & 0.5 & & & \\
\hline \multirow{2}{*}{ B-gr4 $(n=4)$} & 72.7 & 0.52 & 14.2 & 3.39 & 0.131 & 0.430 & 1.56 & 3.72 & 3.02 & 0.169 & 0.10 & 0.012 & 97.8 & & & \\
\hline & 0.2 & 0.03 & 0.2 & 0.28 & 0.017 & 0.044 & 0.09 & 0.15 & 0.05 & 0.018 & 0.04 & 0.012 & 0.3 & & & \\
\hline \multirow{2}{*}{$\begin{array}{l}\text { B-gr6-dark } \\
(\mathrm{n}=2 ; \text { brown } \\
\text { glass) }\end{array}$} & 73.2 & 0.51 & 13.9 & 3.09 & 0.11 & 0.45 & 1.72 & 3.79 & 2.98 & 0.161 & 0.10 & 0.005 & 97.0 & & & \\
\hline & 0.9 & 0.04 & 0.2 & 0.53 & 0.059 & 0.269 & 0.46 & 0.03 & 0.04 & 0.025 & 0.01 & 0.007 & 0.2 & & & \\
\hline \multirow{2}{*}{$\begin{array}{l}\text { B-gr7-dark } \\
\text { ( } \mathrm{n}=3 ; \text { brown } \\
\text { glass) }\end{array}$} & 72.2 & 0.64 & 14.1 & 3.31 & 0.12 & 0.44 & 1.85 & 3.85 & 3.16 & 0.166 & 0.12 & 0.005 & 94.5 & & & \\
\hline & 1.0 & 0.04 & 0.1 & 0.46 & 0.078 & 0.123 & 0.16 & 0.10 & 0.03 & 0.013 & 0.03 & 0.009 & 0.4 & & & \\
\hline \multirow{2}{*}{$\begin{array}{l}\text { F-gr3 (obsidian } \\
\text { chip; } \mathrm{n}=3 \text { ) }\end{array}$} & 70.9 & 0.69 & 14.6 & 3.95 & 0.14 & 0.56 & 2.00 & 4.12 & 2.78 & 0.185 & 0.11 & 0.017 & 97.5 & & & \\
\hline & 0.5 & 0.02 & 0.1 & 0.04 & 0.025 & 0.031 & 0.02 & 0.19 & 0.05 & 0.007 & 0.01 & 0.015 & 0.6 & & & \\
\hline \multirow{2}{*}{$\begin{array}{l}\text { F-gr4 (obsidian } \\
\text { chip; } \mathrm{n}=2)\end{array}$} & 71.4 & 0.61 & 14.1 & 4.04 & 0.16 & 0.43 & 1.75 & 4.23 & 2.96 & 0.206 & 0.08 & 0.018 & 98.4 & & & \\
\hline & 0.2 & 0.01 & 0.0 & 0.01 & 0.018 & 0.008 & 0.06 & 0.06 & 0.07 & 0.005 & 0.00 & 0.004 & 0.3 & & & \\
\hline \multicolumn{17}{|c|}{ Glass inclusions Plinian } \\
\hline \multirow{2}{*}{$\begin{array}{l}\text { F-gr4-glinc } \\
(\mathrm{n}=2)\end{array}$} & 72.1 & 0.49 & 14.0 & 3.83 & 0.13 & 0.49 & 1.56 & 4.17 & 2.98 & 0.212 & 0.07 & 0.027 & 95.9 & 1.19 & 1.11 & b.d.l. \\
\hline & 0.0 & 0.03 & 0.0 & 0.29 & 0.002 & 0.041 & 0.04 & 0.09 & 0.01 & 0.005 & 0.01 & 0.022 & 0.0 & & & \\
\hline \multirow{2}{*}{$\begin{array}{l}\text { spec02 wht- } \\
\text { glinc1 }(n=2)\end{array}$} & 72.8 & 0.73 & 13.7 & 3.79 & 0.08 & 0.50 & 1.77 & 3.45 & 2.93 & 0.200 & 0.11 & 0.000 & 96.5 & 0.96 & 0.83 & b.d.l. \\
\hline & 0.2 & 0.26 & 0.2 & 0.61 & 0.063 & 0.066 & 0.06 & 0.02 & 0.14 & 0.040 & 0.02 & 0.000 & 0.4 & & & \\
\hline \multirow{2}{*}{$\begin{array}{l}\text { A-gr37-glinc } \\
(\mathrm{n}=3)\end{array}$} & 70.6 & 0.82 & 14.3 & 4.77 & 0.13 & 0.57 & 1.93 & 3.81 & 2.74 & 0.195 & 0.13 & 0.023 & 97.3 & 0.99 & 0.78 & b.d.l. \\
\hline & 0.1 & 0.11 & 0.1 & 0.65 & 0.040 & 0.037 & 0.04 & 0.29 & 0.07 & 0.016 & 0.01 & 0.019 & 0.5 & & & \\
\hline $\begin{array}{l}\text { spec01wht- } \\
\text { glinc1 }(\mathrm{n}=1)\end{array}$ & 72.0 & 0.51 & 13.4 & 4.24 & 0.19 & 0.78 & 1.67 & 4.11 & 2.99 & 0.190 & 0.09 & 0.022 & 96.9 & 0.98 & 0.76 & $38-43$ \\
\hline $\begin{array}{l}\text { glinc1_CC } \\
(\mathrm{n}=1)\end{array}$ & 72.3 & 0.66 & 14.1 & 3.78 & 0.15 & 0.54 & 1.66 & 4.00 & 3.20 & 0.198 & 0.12 & 0.001 & 96.0 & 1.02 & 0.88 & b.d.1. \\
\hline $\begin{array}{l}\text { glinc2_CC } \\
(\mathrm{n}=1)\end{array}$ & 72.0 & 0.70 & 13.8 & 4.40 & 0.14 & 0.59 & 1.80 & 3.90 & 2.77 & 0.172 & 0.08 & 0.007 & 96.5 & 1.23 & 0.92 & b.d.l. \\
\hline $\begin{array}{l}\text { glinc3_CC } \\
(\mathrm{n}=1)\end{array}$ & 71.7 & 0.72 & 14.9 & 3.87 & 0.13 & 0.48 & 1.67 & 3.40 & 2.90 & 0.180 & 0.10 & 0.009 & 97.0 & 1.06 & 0.84 & $63-71$ \\
\hline $\begin{array}{l}\text { glinc4_CC } \\
(\mathrm{n}=1)\end{array}$ & 72.0 & 0.66 & 14.0 & 4.00 & 0.12 & 0.47 & 1.70 & 3.42 & 3.30 & 0.188 & 0.10 & 0.010 & 96.8 & 1.11 & 0.82 & $55-62$ \\
\hline $\begin{array}{l}\text { glinc5_CC } \\
(\mathrm{n}=1)\end{array}$ & 72.4 & 0.55 & 14.4 & 3.90 & 0.15 & 0.46 & 1.94 & 4.30 & 2.92 & 0.210 & 0.09 & 0.003 & 95.9 & 0.87 & 0.79 & $46-52$ \\
\hline $\begin{array}{l}\text { glinc6_CC } \\
(\mathrm{n}=1)\end{array}$ & 72.8 & 0.70 & 13.6 & 4.10 & 0.14 & 0.59 & 2.00 & 4.10 & 2.76 & 0.208 & 0.13 & 0.006 & 97.2 & 0.91 & 0.86 & $51-58$ \\
\hline $\begin{array}{l}\text { glinc7_CC } \\
(\mathrm{n}=1)\end{array}$ & 73.0 & 0.81 & 13.7 & 4.60 & 0.12 & 0.54 & 2.10 & 4.50 & 2.80 & 0.173 & 0.15 & 0.011 & 96.3 & 1.26 & 1.12 & b.d.l. \\
\hline $\begin{array}{l}\text { glinc7b_CC } \\
(\mathrm{n}=1)\end{array}$ & 71.0 & 0.44 & 14.3 & 4.70 & 0.13 & 0.66 & 1.90 & 4.70 & 3.50 & 0.178 & 0.11 & 0.014 & 96.4 & 0.86 & 0.72 & b.d.1. \\
\hline glinc8_CC & 72.6 & 0.56 & 13.9 & 3.84 & 0.15 & 0.70 & 1.99 & 3.90 & 2.82 & 0.199 & 0.12 & 0.020 & 97.8 & 0.44 & 0.30 & b.d.l. \\
\hline
\end{tabular}




\begin{tabular}{|c|c|c|c|c|c|c|c|c|c|c|c|c|c|c|c|c|}
\hline Sample & $\mid$\begin{tabular}{|l|}
$\mathrm{SiO}_{2}$ \\
\end{tabular} & $\mathbf{T i O}_{2}$ & $\mathbf{A l}_{2} \mathbf{O}_{3}$ & $\mathrm{FeO}$ & MnO & MgO & $\mathrm{CaO}$ & $\mathrm{Na}_{2} \mathrm{O}$ & $\mathbf{K}_{2} \mathbf{O}$ & Cl & $\mathbf{P}_{2} \mathbf{O}_{5}$ & $\mathrm{SO}_{3}$ & Total $^{\text {b }}$ & $\mathbf{O H}$ & $\mathrm{H}_{2} \mathrm{O}^{\mathrm{c}}$ & $\begin{array}{l}\mathrm{CO}_{2} \\
(\mathbf{p p m})^{\mathrm{d}}\end{array}$ \\
\hline \multirow{2}{*}{\multicolumn{17}{|c|}{ Glass inclusions LAVA }} \\
\hline & & & & & & & & & & & & & & & & \\
\hline $\begin{array}{l}\text { PlavaAglincb1 } \\
(\mathrm{n}=1)\end{array}$ & 71.2 & 0.45 & 15.1 & 2.23 & 0.056 & 0.042 & 0.613 & 4.75 & 4.67 & 0.249 & 0.118 & 0.01 & 99.6 & ND & ND & ND \\
\hline $\begin{array}{l}\text { PlavaAglincb2 } \\
(\mathrm{n}=1)\end{array}$ & 71.5 & 0.51 & 15.0 & 2.42 & 0.058 & 0.066 & 0.603 & 4.31 & 4.61 & 0.274 & 0.12 & 0 & 99.6 & ND & ND & ND \\
\hline \multicolumn{17}{|c|}{$\begin{array}{l}{ }^{\text {a}} \text { All oxides are reported as normalized to } 100 \% \text { anhydrous values } \\
{ }^{b} \text { Totals are the raw unnormalized value } \\
{ }^{\circ} \text { Molecular } \mathrm{H}_{2} \mathrm{O} \\
{ }^{\mathrm{d}} \text { Minimum and maximum } \mathrm{CO}_{2} \text { contents reported and derived from the Behrens et al. (2004; minimum) and Blank (1993; } \\
\text { maximum) calibrations of the molcular } \mathrm{CO}_{2} \text { absorption coefficients } \\
\text { Values in italics indicate } 1 \mathrm{SD}\end{array}$} \\
\hline
\end{tabular}

Table 3

Experimental conditions and results for the 2011 Cordón Caulle rhyolite

\begin{tabular}{|c|c|c|c|c|c|}
\hline Experiment & Temperature $\left({ }^{\circ} \mathbf{C}\right)$ & Pressure (MPa) & Duration (h) & $\varnothing(\operatorname{vol.\% })^{\mathrm{a}}$ & Assemblage \\
\hline puy1 & 900 & 100 & 93 & 4 & gl, opx, cpx, mt, ilm, and ap \\
\hline puy2 & 850 & 100 & 96 & 14 & $\mathrm{gl}, \mathrm{pl}, \mathrm{opx}, \mathrm{cpx}, \mathrm{mt}, \mathrm{ilm}$, and ap \\
\hline puy3 & 800 & 100 & 126 & ND & $\mathrm{gl}, \mathrm{pl}, \mathrm{amph}, \mathrm{opx}, \mathrm{cpx}, \mathrm{mt}, \mathrm{ilm}$, and ap \\
\hline puy4 & 750 & 100 & 68 & ND & $\mathrm{gl}, \mathrm{pl}, \mathrm{amph}, \mathrm{opx}, \mathrm{cpx}, \mathrm{mt}, \mathrm{ilm}$, and ap \\
\hline puy5 & 925 & 100 & 142 & 0.1 & gl, ap, and ilm \\
\hline puy6 & 850 & 200 & 48 & 9 & $\mathrm{gl}, \mathrm{amph}, \mathrm{opx}, \mathrm{cpx}, \mathrm{mt}$, and ilm \\
\hline puy7 & 800 & 200 & 56 & 20 & $\mathrm{gl}, \mathrm{pl}$, amph, cpx, mt, ilm, and ap \\
\hline puy8 & 900 & 200 & 24 & 0.7 & $\mathrm{mt}$, ilm, and ap \\
\hline puy9 & 900 & 50 & 140 & 12 & $\mathrm{gl}, \mathrm{pl}, \mathrm{opx}, \mathrm{cpx}, \mathrm{mt}$, and ap \\
\hline puy10 & 925 & 50 & 98 & 8 & $\mathrm{gl}, \mathrm{pl}, \mathrm{opx}, \mathrm{cpx}, \mathrm{mt}$, ilm, and ap \\
\hline puy11 & 850 & 50 & 98 & 46 & $\mathrm{gl}, \mathrm{pl}, \mathrm{opx}, \mathrm{cpx}, \mathrm{mt}$, ilm, and ap \\
\hline puy12 & 800 & 50 & 90 & 55 & $\mathrm{gl}, \mathrm{pl}, \mathrm{opx}, \mathrm{cpx}, \mathrm{mt}$, and ilm \\
\hline puy13 & 750 & 200 & 70 & 45 & $\mathrm{gl}, \mathrm{pl}, \mathrm{amph}, \mathrm{opx}, \mathrm{cpx}, \mathrm{mt}, \mathrm{ilm}$, and ap \\
\hline puy14 & 825 & 75 & 94 & 52 & $\mathrm{gl}, \mathrm{pl}, \mathrm{opx}, \mathrm{cpx}, \mathrm{mt}$, and ap \\
\hline puy15 & 875 & 75 & 72 & 14 & $\mathrm{gl}, \mathrm{pl}, \mathrm{opx}, \mathrm{cpx}, \mathrm{mt}$, ilm, and ap \\
\hline puy16 & 925 & 200 & 24 & 0.1 & gl, ilm, and ap \\
\hline puy17 & 825 & 150 & 190 & 13 & $\mathrm{gl}, \mathrm{pl}, \mathrm{amph}, \mathrm{cpx}, \mathrm{mt}, \mathrm{ilm}$, and ap \\
\hline puy18 & 875 & 125 & 123 & 6 & gl, opx, cpx, mt, and ilm \\
\hline puy19 & 875 & 170 & 95 & 3 & $\mathrm{gl}, \mathrm{opx}, \mathrm{cpx}, \mathrm{mt}$, and ilm \\
\hline puy20 & 975 & 50 & 48 & 0 & gl \\
\hline puy 21 & 900 & 20 & 312 & 43 & $\mathrm{gl}, \mathrm{pl}, \mathrm{opx}, \mathrm{cpx}, \mathrm{mt}$, and ap \\
\hline puy 22 & 950 & 20 & 312 & 20 & $\mathrm{gl}, \mathrm{pl}, \mathrm{opx}, \mathrm{cpx}, \mathrm{mt}, \mathrm{ilm}$, and ap \\
\hline puy 23 & 850 & 20 & 264 & 62 & $\mathrm{gl}, \mathrm{pl}, \mathrm{opx}, \mathrm{cpx}, \mathrm{mt}, \mathrm{ilm}$, and ap \\
\hline puy 27 & 875 & 100 & 68 & 5 & $\mathrm{gl}, \mathrm{pl}, \mathrm{opx}, \mathrm{cpx}, \mathrm{mt}, \mathrm{ilm}$, and ap \\
\hline puy 29 & 900 & 75 & 71 & 6 & $\mathrm{gl}, \mathrm{pl}, \mathrm{opx}, \mathrm{cpx}, \mathrm{mt}, \mathrm{ilm}$, and ap \\
\hline puy R32 ${ }^{\mathrm{b}}$ & 800 & 200 & 232 & 18 & $\mathrm{gl}, \mathrm{pl}, \mathrm{amph}, \mathrm{cpx}, \mathrm{mt}, \mathrm{ilm}$, and ap \\
\hline puy R33 ${ }^{\mathrm{b}}$ & 875 & 75 & 210 & 11 & $\mathrm{gl}, \mathrm{pl}, \mathrm{opx}, \mathrm{cpx}, \mathrm{mt}, \mathrm{ilm}$, and ap \\
\hline puy R34 ${ }^{\mathrm{b}}$ & 900 & 50 & 215 & 10 & $\mathrm{gl}, \mathrm{pl}, \mathrm{opx}, \mathrm{cpx}, \mathrm{mt}$, and ap \\
\hline puy R35 ${ }^{\mathrm{b}}$ & 825 & 150 & 211 & 14 & $\mathrm{gl}, \mathrm{pl}, \mathrm{amph}, \mathrm{cpx}, \mathrm{mt}, \mathrm{ilm}$, and ap \\
\hline puy R36 ${ }^{\mathrm{b}}$ & 875 & 100 & 192 & 4 & $\mathrm{gl}, \mathrm{pl}, \mathrm{opx}, \mathrm{cpx}, \mathrm{mt}, \mathrm{ilm}$, and ap \\
\hline puy R37 ${ }^{\text {b }}$ & 950 & 130 & 24 & 0 & $\mathrm{gl}$ \\
\hline
\end{tabular}

gl glass, pl plagioclase, amph amphibole, opx orthopyroxene, cpx clinopyroxene, mt magnetite, ilm ilmenite, ap apatite ${ }^{a}$ Volume percent crystals determined by image analysis on $2 \mathrm{D}$ backscattered electron images

${ }^{\mathrm{b}}$ Reversal experiment 
Table 4

Glass compositions from experiments on the 2011 Cordón Caulle rhyolite as determined by EPMA

\begin{tabular}{|c|c|c|c|c|c|c|c|c|c|c|c|c|c|c|}
\hline Expe & $\mathrm{SiO}_{2}$ & $\mathrm{TiO}_{2}$ & $\mathrm{Al}_{2} \mathrm{O}_{3}$ & $\mathrm{FeO}$ & MnO & MgO & $\mathbf{F}$ & $\mathrm{CaO}$ & $\mathrm{Na}_{2} \mathrm{O}$ & $\mathbf{K}_{2} \mathbf{O}$ & Cl & $\mathbf{P}_{2} \mathbf{O}_{5}$ & $\mathrm{SO}_{3}$ & Tota \\
\hline \multirow{2}{*}{ Puy_1 (n=9) } & 70.3 & 0.55 & 14.6 & 3.40 & 0.10 & 0.54 & 0.043 & 2.06 & 5.43 & 2.77 & 0.118 & 0.08 & 0.013 & 96.4 \\
\hline & 0.2 & 0.03 & 0.1 & 0.16 & 0.04 & 0.03 & 0.056 & 0.04 & 0.09 & 0.03 & 0.005 & 0.02 & 0.013 & 0.4 \\
\hline \multirow{2}{*}{ Puy_2 $(\mathrm{n}=8)$} & 73.0 & 0.32 & 14.5 & 2.02 & 0.11 & 0.28 & 0.041 & 1.45 & 5.01 & 3.00 & 0.113 & 0.10 & 0.007 & 94.1 \\
\hline & 1.0 & 0.02 & 0.1 & 0.06 & 0.02 & 0.02 & 0.040 & 0.10 & 0.09 & 0.08 & 0.008 & 0.05 & 0.010 & 1.0 \\
\hline \multirow{2}{*}{ Puy_3 $(\mathrm{n}=10)$} & 74.4 & 0.26 & 13.9 & 1.68 & 0.06 & 0.16 & 0.024 & 1.05 & 4.89 & 3.33 & 0.140 & 0.06 & 0.002 & 94.4 \\
\hline & 0.2 & 0.04 & 0.2 & 0.19 & 0.04 & 0.01 & 0.028 & 0.07 & 0.29 & 0.09 & 0.003 & 0.02 & 0.004 & 0.5 \\
\hline \multirow{2}{*}{ Puy_4 $(\mathrm{n}=6)$} & 74.2 & 0.29 & 13.9 & 1.91 & 0.06 & 0.23 & 0.084 & 1.37 & 4.51 & 3.21 & 0.106 & 0.08 & 0.006 & 94.5 \\
\hline & 1.4 & 0.14 & 0.8 & 0.70 & 0.03 & 0.08 & 0.069 & 0.41 & 0.50 & 0.32 & 0.012 & 0.01 & 0.009 & 0.7 \\
\hline \multirow{2}{*}{ Puy_6 $(\mathrm{n}=9)$} & 71.3 & 0.36 & 15.0 & 2.38 & 0.11 & 0.38 & 0.091 & 1.95 & 5.42 & 2.77 & 0.086 & 0.13 & 0.006 & 91.7 \\
\hline & 0.5 & 0.04 & 0.1 & 0.22 & 0.04 & 0.04 & 0.049 & 0.17 & 0.21 & 0.05 & 0.008 & 0.13 & 0.012 & 0.6 \\
\hline \multirow{2}{*}{ Puy_7 $(\mathrm{n}=10)$} & 75.6 & 0.23 & 15.4 & 1.60 & 0.17 & 0.19 & 0.013 & 1.71 & 2.79 & 2.05 & 0.083 & 0.11 & 0.012 & 89.5 \\
\hline & 0.6 & 0.03 & 0.1 & 0.20 & 0.12 & 0.01 & 0.032 & 0.18 & 0.46 & 0.19 & 0.012 & 0.15 & 0.012 & 0.5 \\
\hline \multirow{2}{*}{ Puy $8(n=8)$} & 69.7 & 0.63 & 14.5 & 3.75 & 0.11 & 0.69 & 0.045 & 2.20 & 5.50 & 2.71 & 0.100 & 0.11 & 0.006 & 95.2 \\
\hline & 0.2 & 0.03 & 0.1 & 0.19 & 0.05 & 0.03 & 0.054 & 0.04 & 0.08 & 0.03 & 0.009 & 0.01 & 0.008 & 0.4 \\
\hline \multirow{2}{*}{ Puy_9 $(\mathrm{n}=9)$} & 72.4 & 0.46 & 13.8 & 2.60 & 0.09 & 0.34 & 0.045 & 1.36 & 5.53 & 3.08 & 0.128 & 0.09 & 0.012 & 98.7 \\
\hline & 0.5 & 0.02 & 1 & 0.18 & 0.04 & 0.03 & 0.042 & 0.06 & 0.19 & 0.06 & 0.008 & 0.03 & 0.013 & 0.7 \\
\hline \multirow{2}{*}{ Puy_10 $(\mathrm{n}=9)$} & 70.5 & 0.62 & 14.4 & 3.23 & 0.09 & 0.52 & 53 & 1.88 & 5.69 & 2.86 & 0.119 & 0.11 & 0.010 & 98.8 \\
\hline & 0.6 & 0.03 & 0.1 & 0.12 & 0.05 & 0.02 & 49 & 0.05 & 0.06 & 0.04 & 0.011 & 0.04 & 0.010 & 0.7 \\
\hline \multirow{2}{*}{ Puy_11 $(\mathrm{n}=7)$} & 74.5 & 0.36 & 13.3 & 1.83 & 0 & 0.24 & 49 & 1 & 4.96 & 44 & 47 & 07 & 004 & 9 \\
\hline & 1.0 & 0.09 & 0.7 & 0.24 & 0 & 12 & 47 & 0 & 0.31 & 19 & 0.008 & 04 & .009 & \\
\hline \multirow{2}{*}{ Puy_13 $(\mathrm{n}=6)$} & 74.5 & 0.21 & $\mid$ & 1.29 & 0.07 & 0.13 & 0.037 & 1.15 & 5.06 & 3.27 & 0.068 & 0.05 & 0.010 & 91.6 \\
\hline & 0.1 & 0.04 & 2 & 0.11 & 0.04 & 0.02 & 31 & 77 & 0.16 & 0.09 & 0.005 & 0.03 & 0.014 & 0.2 \\
\hline \multirow{2}{*}{ Puy_14 (n=9) } & 74.5 & 0.37 & |15.4 & 1.74 & 0.09 & 0.17 & 82 & 0.88 & 5.04 & 3.47 & 0.136 & 0.08 & 0.009 & 97.7 \\
\hline & 0.6 & 0.15 & 0.1 & 0.33 & 0.04 & 0.02 & 0.068 & 0.07 & 0.19 & 0.07 & 0.009 & 0.04 & 0.014 & 0.4 \\
\hline \multirow{2}{*}{ Puy_15 (n=8) } & 72.4 & 0.47 & 14.4 & 2.36 & 0.11 & 0.33 & 0.012 & 1.41 & 5.29 & 3.04 & 0.122 & 0.07 & 0.009 & 98.0 \\
\hline & 0.2 & 0.09 & 0.1 & 0.28 & 0.03 & 0.01 & 0.033 & 0.03 & 0.11 & 0.05 & 0.007 & 0.02 & 0.012 & 0.3 \\
\hline \multirow{2}{*}{ Puy_17 (n=12) } & 72.8 & 0.29 & 14.8 & 1.75 & 0.09 & 0.26 & 0.043 & 1.49 & 5.42 & 2.96 & 0.108 & 0.03 & 0.011 & 93.8 \\
\hline & 0.8 & 0.07 & 0.1 & 0.06 & 0.04 & 0.02 & 0.053 & 0.03 & 0.56 & 0.10 & 0.007 & 0.02 & 0.011 & 0.5 \\
\hline \multirow{2}{*}{ Puy_18 $(\mathrm{n}=16)$} & 71.5 & 0.47 & 15.0 & 2.57 & 0.13 & 0.44 & 0.015 & 1.91 & 4.97 & 2.86 & 0.118 & 0.07 & 0.011 & 93.7 \\
\hline & 0.4 & 0.04 & 0.1 & 0.11 & 0.02 & 0.01 & 0.017 & 0.02 & 0.28 & 0.04 & 0.007 & 0.02 & 0.012 & 0.8 \\
\hline \multirow{2}{*}{ Puy_19 $(n=20)$} & 70.8 & 0.47 & 14.8 & 2.46 & 0.12 & 0.46 & 0.060 & 2.08 & 5.73 & 2.77 & 0.094 & 0.14 & 0.013 & 95.4 \\
\hline & 0.8 & 0.03 & 0.1 & 0.12 & 0.02 & 0.02 & 0.038 & 0.22 & 0.15 & 0.06 & 0.004 & 0.18 & 0.009 & 0.8 \\
\hline \multirow{2}{*}{ Puy_20 (n=11) } & 69.5 & 0.68 & 14.3 & 3.80 & 0.14 & 0.69 & 0.043 & 2.23 & 5.62 & 2.76 & 0.119 & 0.14 & 0.009 & 97.7 \\
\hline & 0.3 & 0.04 & 0.1 & 0.10 & 0.04 & 0.02 & 0.047 & 0.04 & 0.12 & 0.04 & 0.006 & 0.02 & 0.010 & 0.3 \\
\hline \multirow{2}{*}{ Puy_29 $(\mathrm{n}=10)$} & 70.7 & 0.55 & 14.5 & 2.85 & 0.10 & 0.49 & 0.034 & 1.97 & 5.74 & 2.83 & 0.136 & 0.10 & 0.009 & 97.6 \\
\hline & 0.2 & 0.04 & 0.1 & 0.09 & 0.04 & 0.01 & 0.043 & 0.04 & 0.09 & 0.05 & 0.007 & 0.05 & 0.011 & 0.2 \\
\hline $\mathrm{Pu}_{\mathrm{w}}$ & 72.6 & 0.31 & 14.9 & 1.56 & 0.08 & 0.19 & 0.042 & 1.69 & 5.58 & 2.89 & 0.081 & 0.11 & 0.010 & 94.6 \\
\hline Puy_R32 $(n=9)$ & 0.4 & 0.04 & 0.2 & 0.44 & 0.03 & 0.02 & 0.043 & 0.08 & 0.13 & 0.06 & 0.005 & 0.05 & 0.012 & 0.3 \\
\hline & 73.3 & 0.40 & 13.8 & 2.12 & 0.10 & 0.32 & 0.091 & 1.32 & 5.26 & 3.09 & 0.097 & 0.08 & 0.015 & 97.1 \\
\hline & 0.4 & 0.01 & 0.1 & 0.08 & 0.04 & 0.03 & 0.067 & 0.08 & 0.14 & 0.06 & 0.005 & 0.03 & 0.015 & 0.6 \\
\hline & 71.9 & 0.52 & 14.3 & 2.43 & 0.10 & 0.41 & 0.053 & 1.49 & 5.45 & 3.16 & 0.143 & 0.10 & 0.011 & 98.3 \\
\hline & 0.9 & 0.06 & 0.3 & 0.13 & 0.05 & 0.02 & 0.060 & 0.10 & 0.09 & 0.04 & 0.010 & 0.06 & 0.013 & 0.5 \\
\hline & 72.5 & 0.30 & 14.8 & 1.68 & 0.10 & 0.26 & 0.057 & 1.38 & 5.64 & 3.14 & 0.151 & 0.05 & 0.016 & 96.3 \\
\hline & 0.5 & 0.02 & 0.3 & 0.08 & 0.04 & 0.03 & 0.052 & 0.06 & 0.10 & 0.05 & 0.007 & 0.02 & 0.015 & 0.4 \\
\hline & 71.5 & 0.43 & 14.8 & 2.50 & 0.10 & 0.39 & 0.038 & 1.87 & 5.47 & 2.74 & 0.130 & 0.08 & 0.008 & 97.0 \\
\hline & 0.4 & 0.03 & 0.1 & 0.11 & 0.03 & 0.02 & 0.051 & 0.07 & 0.05 & 0.09 & 0.010 & 0.04 & 0.012 & 0.6 \\
\hline
\end{tabular}

Values set in italics are $1 \mathrm{SD}$ 
${ }^{a}$ Number of analyses in parentheses

${ }^{b}$ Oxide data reported as normalized to $100 \%$ anhydrous

${ }^{\mathrm{c}}$ Total reflects before normalization value 